UNIVERSIDADE DE BRASÍLIA - UNB

FACULDADE DE ECONOMIA, ADMINISTRAÇÃO, CONTABILIDADE E CIÊNCIA DA INFORMAÇÃO E DOCUMENTAÇÃO (FACE)

CELSO ROBERTO DE SOUZA

OS IMPACTOS DA SUBSTITUIÇÃO TRIBUTÁRIA NAS EMPRESAS ESTATAIS 
CELSO ROBERTO DE SOUZA

\title{
OS IMPACTOS DA SUBSTITUIÇÃO TRIBUTÁRIA NAS EMPRESAS ESTATAIS.
}

\begin{abstract}
Monografia apresentada ao Programa de Pós-Graduação em Administração (PPGA) da Faculdade de Economia, Administração, Contabilidade e Ciência da Informação e Documentação (FACE), da Universidade de Brasília, como requisito à obtenção do grau de Especialista em Orçamento e Finanças.
\end{abstract}

Orientador: Prof. Paulo Henrique Feijó da Silva. 


\section{RESUMO}

O objeto deste trabalho é demonstrar aos estudiosos da matéria, aos administradores das empresas públicas, e se possível aos administradores públicos responsáveis pela arrecadação dos municípios, os custos advindos com a imputação da substituição tributária imposta à empresas públicas. Os municípios no afã de reduzir a sonegação fiscal e assim aumentar a arrecadação, oriunda dos tributos da alçada da municipalidade, responsabilizou as empresas da administração pública indireta, pela retenção na fonte do Imposto sobre Serviços de Qualquer Natureza - ISSQN, seu recolhimento, e ainda ao cumprimento das obrigações acessórias conseqüentes, transformando-as em substitutas tributárias fato que resultou num aumento dos recursos dispendidos com pagamento de salários, encargos trabalhistas e manutenção de sistemas informatizados. A guerra fiscal, também motivo deste trabalho, foi outro fator preponderante para que algumas prefeituras implantassem mecanismos que beneficia empresas interessadas em se instalarem em municípios com carga tributária menor. Enquanto não se aprova a reforma tributária, as empresas vão tendo que sobreviver com as regras leoninas impostas pelos códigos tributários municipais, e ainda correndo sérios riscos quando o assunto esta relacionado com o cumprimento pontual da retenção de impostos em todos os documentos dos prestadores de serviços que se encontrem instalados no âmbito dos municípios, e também em casos especiais, de fornecedores que não se encontram sediados no município onde prestam serviços. Há também que se informar sobre as dificuldades que as empresas encontram quando precisam reaver valores recolhidos indevidamente, ou em duplicidade. Nestes casos os processos administrativos protocolados nos órgãos responsáveis das prefeituras, são morosos, e em muitos dos casos restituídos muitos anos depois da ocorrência do fato.

Palavras-chave: Sonegação Fiscal. Substituição Tributária. Reforma Tributária. Guerra Fiscal. 


\section{LISTA DE FIGURAS}

Figura 1 - Gastos Mensais com Pessoal .............................................................. $\quad 39$

Figura 2 - Gastos Anuais com Pessoal ………....................................................... 40

Figura 3 - Quantidade média de Documentos …....................................................... 40

Figura 4 - Modelo de Planilha utilizada .................................................................. 42

Figura 5 - Tela de registro das obrigações no SIAFI - Dados Básicos ........................ 43

Figura 6 - Tela de registro das obrigações no SIAFI - Dados Contábeis .................... 43

Figura 7 - Tela de registro das obrigações no SIAFI - Deduções e Encargos ............. 44

Figura 8 - Tela de registro das obrigações no SIAFI - Dedução - GPS ....................... 44

Figura 9 - Tela de registro das obrigações no SIAFI - Dedução - Impostos Federais. 45

Figura 10 - Tela de registro das obrigações no SIAFI - Dedução ISSQN ................... 45

Figura 11- Tela de registro das obrigações no SIAFI - Confirmação do Registro ...... 46

Figura 12 - Médias de Documentos de Arrecadação - DAR ........................................ 49 


\section{LISTA DE QUADROS}

Quadro 1 - Remuneração média mensal dos empregados envolvidos ...................... 38

Quadro 2 - Encargos Trabalhistas Aplicado sobre a Remuneração Mensal ............... 39

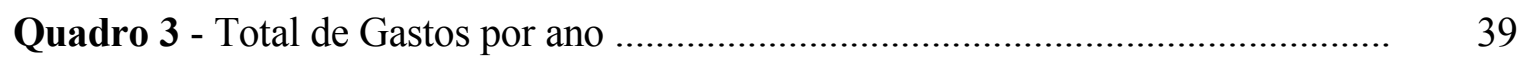

Quadro 4 - Quantidade média de Documentos Fiscais Tratados ............................. $\quad 40$

Quadro 5 - Relação de Municípios ........................................................................ 47

Quadro 6 - Quantidade média anual de Documento de Arrecadação - DAR ........... 48 


\section{SUMÁRIO}

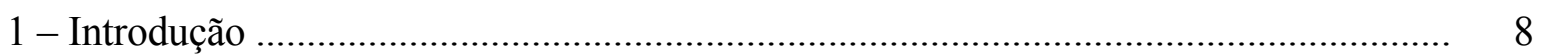

1.1 - Formulação do problema de pesquisa............................................................. 9

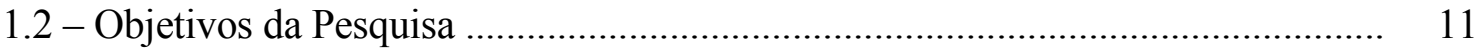

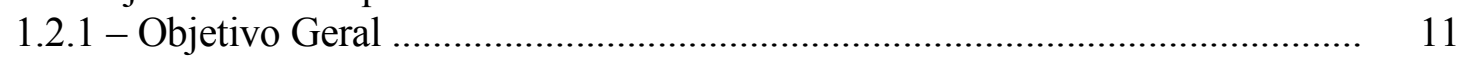

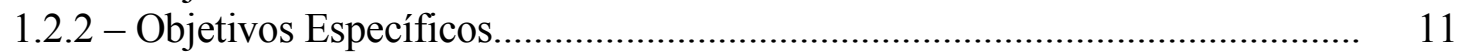

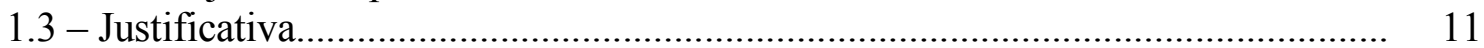

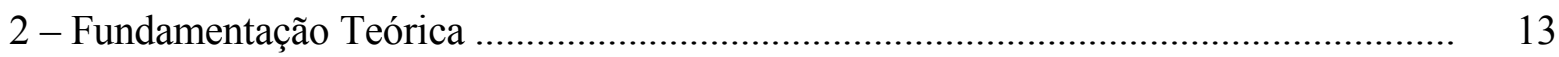

2.1 - Relação comercial entre as empresas estatais e órgãos da administração

pública..

2.2 - Sonegação fiscal............................................................................... 14

2.3 - Guerra fiscal............................................................................... 15

2.4 - Fato gerador da obrigação principal............................................................... 19

2.5 - Fato gerador da obrigação acessória............................................................... 19

2.6 - Sujeito passivo da obrigação tributária................................................................ 20

2.7 - Substituição Tributária................................................................................... 21

2.8 - Imposto sobre serviços de qualquer natureza (ISSQN) ................................... 23

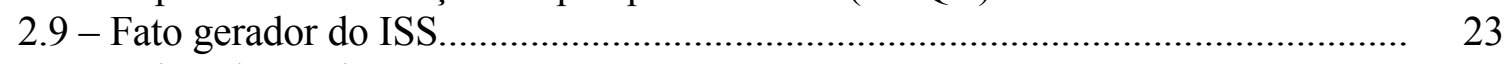

2.10 - Lista de serviços....................................................................................... 24

2.11 - Base de cálculo do ISS............................................................................. 24

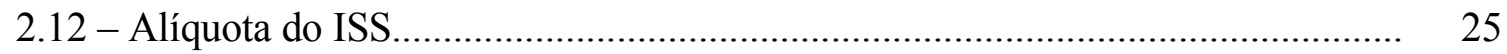

2.13 - Análise dos documentos fiscais.................................................................. 25

2.13.1 - Conferência prévia dos documentos fiscais........................................... 25

2.13.2 - Análise fiscal dos documentos fiscais....................................................... 26

2.14 - Retenção na fonte dos tributos e o recolhimento ……....................................... 27

2.15 - Contabilização e pagamento dos documentos fiscais.......................................... 28

2.15.1 - Contabilização da despesa e do reconhecimento das obrigações................ 29

2.15.2 - Do pagamento ao fornecedor................................................................... 29

2.15.3 - Do recolhimento do imposto................................................................. 29

2.16 - Controle dos impostos retidos na fonte ....................................................... 30

2.17 - Sistema de controle de fornecedores (SICAF) ............................................... $\quad 30$

2.18 - Lei de Licitações....................................................................................... 31

2.19 - Nota Fiscal Eletrônica..................................................................................... 31

2.20 - Sistema Público de Escrituração Digital - SPED .............................................. 33

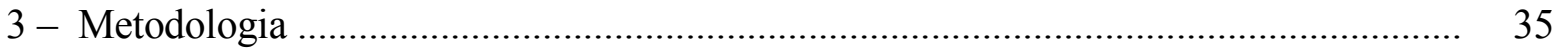

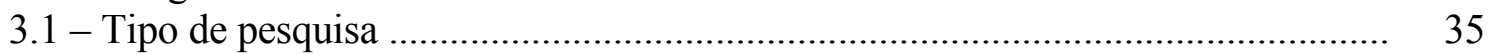

3.2 - Caracterização da organização ........................................................................ 36

3.3 - Participantes da pesquisa e Amostra de Documentos........................................ 36

3.3.1 - Seleção dos Participantes .................................................................... 36

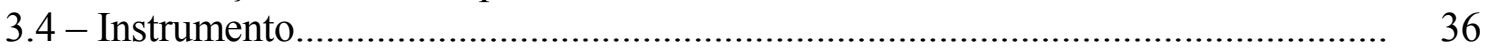

3.5 - Procedimentos de coleta dos dados........................................................... 37

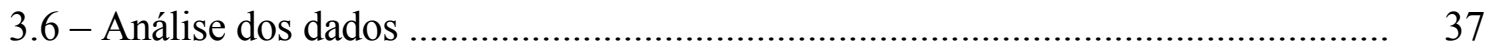




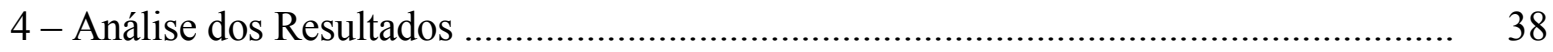

4.1 - Questionário Básico ....................................................................................... $\quad 38$

4.2 - Recursos Tecnológicos Utilizados .................................................................. 41

4.3 - Municípios que já emitem Nota Fiscal Eletrônica ............................................ 47

4.4 - Documento de Arrecadação Municipal ............................................................... 48

4.5 - Descumprimento de Obrigações Acessórias ....................................................... 49

4.6 - Rotinas Internas Desenvolvidas - Obrigações Acessórias ................................. 49

4.7 - Renovação do Quadro de Empregados ............................................................. $\quad 50$

4.8 - Fiscalização Municipal ................................................................................ $\quad 50$

4.9 - Retenção na Fonte por parte de Clientes Públicos ........................................... $\quad 50$

4.10 - Retenções Indevidas ............................................................................. 51

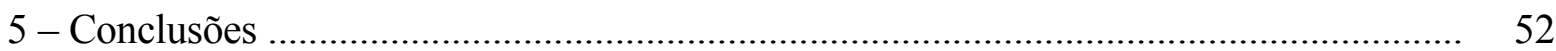

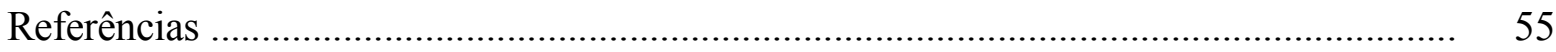




\section{1 - Introdução}

A Reforma Tributária vem sendo objeto de intensos debates nos últimos anos, sem que, todavia, haja sido alcançado um consenso sobre a amplitude e a profundidade das mudanças que precisam ser efetuadas no sistema tributário brasileiro.

Entender que a Reforma Tributária é um processo e não um ato isolado é o primeiro passo para superar divergências. Neste processo é preciso respeitar a história, a cultura, a realidade político-institucional e as peculiaridades da Federação brasileira.

O projeto de emenda constitucional que modifica o sistema tributário brasileiro, enviado pelo Poder Executivo ao Congresso, é um marco deste processo. Ele atende a exigências do momento, promove alterações estruturais de vulto e lança as bases para futuras modificações capazes de atender às necessidades da economia, da sociedade da Federação e principalmente das empresas brasileiras que anseia pela redução da carga tributária que em muito aumenta seus custos, inviabilizando em muitos dos casos a livre concorrência.

Do ponto de vista jurídico, as empresas estatais federais são definidas como "as sociedades anônimas de economia mista e as suas subsidiárias e controladas, as empresas públicas, bem como as demais empresas em que a União, direta ou indiretamente, detenha a maioria do capital social com direito a voto", de acordo com o Departamento de Departamento de Coordenação e Controle das Empresas Estatais (DEST) (BRASIL, 2006). Por serem dotadas de personalidade jurídica de direito privado, estão sujeitas à Lei das Sociedades Anônimas no que se refere aos aspectos constitutivos, organizacionais e de relacionamento com o mercado.

Para fins de controle orçamentário, entretanto, as estatais federais são divididas em dois grupos: (1) as que custeiam suas atividades com recursos próprios ou de mercado, e (2) as que dependem de recursos do orçamento fiscal e da seguridade social para pagar parte ou totalidade de seus gastos correntes, ou seja necessitam de recurso da fonte tesouro.

O primeiro grupamento tem sua previsão de gastos inserida no Programa de Dispêndios Globais (PDG), monitorado pelo DEST, e seus gastos com aquisição e manutenção de bens do Ativo Imobilizado detalhados no Orçamento de Investimentos (OI), que é uma das peças do Orçamento Geral da União (OGU). Já o segundo grupo de empresas dependentes tem todas as suas despesas integradas ao OGU e controladas pela Secretaria de Orçamento Federal (SOF), outra unidade do Ministério do Planejamento. 
A substituição tributária, por fato futuro, foi introduzida na Constituição da República Federativa do Brasil (CF/88) (BRASIL, 1988), pela Emenda Constitucional n 3 (BRASIL, 1993), Art. $1^{\circ}$, que lhe acrescentou ao Art. $150^{\circ}$, o $§ 7^{\circ}$, com a seguinte redação:

A lei poderá atribuir a sujeito passivo a condição de responsável pelo pagamento
de imposto ou contribuição, cujo fato gerador deva ocorrer posteriormente,
assegurada a imediata e preferencial restituição da quantia paga, caso não se
realize o fato gerado presumido.

Sobre o assunto, Carraza (1999) relata que a CF/88 veda a tributação baseada em fatos de provável ocorrência. Para que o mecanismo da substituição tributária venha ser adequadamente utilizado é preciso que se estribe em fatos concretamente ocorridos, nunca em fatos futuros, de ocorrência incerta. Esta é uma barreira constitucional inafastável, pois integra o conjunto de direitos e garantias que a Lei Maior confere ao contribuinte. É ela que sistematicamente interpretada - não admite que haja a substituição tributária "para frente."

Valendo-se do ensinamento de Carraza (1999), ele faz a seguinte indagação: Ora, se pensarmos que o Direito Tributário se formou como um corpo de princípios, altamente preocupados com minúcias do fenômeno da incidência, precisamente para controlar a atividade impositiva e proteger os direitos e garantias dos cidadãos, como admitir um tipo de percussão tributária que se dê à margem de tudo isso, posta a natural imprevisibilidade dos fatos futuros? Se é sempre difícil e problemático exercitar o controle sobre os fatos ocorridos, de que maneira lidar com a incerteza do porvir e, ao mesmo tempo, manter a segurança das relações jurídicas?.

\section{1 - Formulação do problema de pesquisa}

O presente trabalho tem como finalidade apresentar em números, os custos e a carga de trabalho adicional imputada às empresas públicas federais, mais precisamente às empresas estatais de direito privado, na medida em que as prefeituras, de um modo geral, no afã de reduzirem a sonegação e a guerra fiscal, atribuiu àquelas a responsabilidade pela retenção e recolhimento aos cofres municipais, do Imposto Sobre Serviço de Qualquer Natureza (ISSQN), de fornecedores de serviços, bem como do cumprimento de obrigações acessórias que serão mencionadas no decorrer da apresentação.

Além da obrigação de exigir a Nota Fiscal de Serviços, as empresas também precisam observar as legislações municipais que determinam a retenção de tributos na fonte, com a preocupação principal a de não prejudicar o prestador de serviços, lembrando que a responsabilidade pela retenção e recolhimento do imposto, é sempre da fonte pagadora nominada pela administração pública municipal, mesmo que não tenha feito a retenção, a 
chamada responsabilidade solidária, ou seja, em função da natureza do serviço prestado, cada legislação estabelece se o mesmo está sujeito à retenção do ISSQN.

Ocorre que em função de centralização de pagamentos, alguns órgãos e empresas públicas, encontram dificuldades em cumprir a legislação, pois, além do trabalho de reconhecimento dos tributos a serem retidos, ainda há a operacionalização do pagamento do imposto que deve ser direcionado para a prefeitura onde está instalado o domicílio do prestador dos serviços.

Outro dificultador para o cumprimento das obrigações perante os fornecedores está no fato de que as empresas precisam oficializar que realizaram a retenção e comprovar o pagamento do imposto, pois do contrário, o ciclo entre a emissão do documento fiscal por parte do prestador dos serviços, o cumprimento das obrigações acessórias, a retenção e o recolhimento do imposto sobre serviços, não se encerra, ficando tanto o prestador como o tomador do serviço pendente do cumprimento total do fato legal.

No intuito de dar visibilidade sobre a responsabilidade tributária imputada aos órgãos da administração pública, e a conseqüente aplicação de multas pelo não cumprimento das obrigações legais, há que se citar: o Código Tributário Nacional (CTN), que em seu Art. 121 (BRASIL, 1966), define como sujeito passivo da obrigação tributária principal, a pessoa obrigada ao pagamento de tributo, sendo que no inciso I, do parágrafo único do mesmo artigo, define contribuinte, quando há relação pessoal e direta com a situação que constitua o respectivo fato gerador.

Já o Art.128 , ainda do CTN, dispõe que a lei pode atribuir de modo expresso a responsabilidade pelo crédito tributário a terceira pessoa, vinculada ao fato gerador da respectiva obrigação, excluindo a responsabilidade do contribuinte ou atribuindo-a a este em caráter supletivo do cumprimento total ou parcial da referida obrigação.

A Lei Complementar $n^{\circ} 116$ (BRASIL, 2003), em seu Art. $6^{\circ}$, e parágrafo $1^{\circ}$, dispõe:

Art. $6^{\circ}$. Os municípios e o Distrito Federal, mediante lei, poderão atribuir de modo
expresso a responsabilidade pelo crédito tributário a terceira pessoa, vinculada ao
fato gerador da respectiva obrigação, excluindo a responsabilidade do contribuinte
ou atribuindo-a a este em caráter supletivo do cumprimento total ou parcial da
referida obrigação, inclusive no que se refere à multa e aos acréscimos legais.
$\S 1^{\circ}$. Os responsáveis a que se refere este artigo estão obrigados ao recolhimento
integral do imposto devido, multa e acréscimos legais, independentemente de ter
sido efetuada sua retenção na fonte.

Para isso, este estudo tem como questão de pesquisa: quais os custos operacionais e quais as cargas de trabalho que a imposição da responsabilidade tributária trouxe às empresas públicas, no momento em que cabe às estas a retenção na fonte e o respectivo recolhimentos das 
obrigações principais e acessórias, relativo à substituição tributária?

\section{2 - Objetivos da pesquisa}

\subsection{1 - Objetivo geral}

O trabalho tem como objetivo principal, demonstrar o esforço que as áreas de análise fiscal e tributária e da contabilidade das empresas estatais têm que enfrentarem para obedecerem aos requisitos legais, bem como os custos advindos com a operacionalização destas rotinas complexas de trabalho.

\subsection{2 - Objetivos específicos}

Sensibilizar os administradores públicos, a alta gestão, quanto à necessidade de incrementar as áreas envolvidas na atividade da substituição tributária das empresas estatais, com recursos humanos, materiais e sistemas tecnológicos avanços como forma de se mitigar qualquer possibilidade de erros;

$>$ Demonstrar os impactos que a imputação da substituição tributária por parte dos municípios trouxe às empresas estatais;

Analisar as legislações municipais que tratam da substituição tributária;

$>$ Identificar as empresas estatais que foram incluídas na lista de empresas responsabilizadas ao cumprimento de tais obrigações tributárias;

Demonstrar os custos incorridos nas empresas estatais pela imposição da substituição tributária;

$>$ Descrever as novas tecnologias que auxiliam no trabalho operacional da substituição tributária.

Identificar os riscos correlacionados ao processo da substituição tributária;

\section{3 - Justificativa}

Este trabalho visa demonstrar ao corpo diretivo estratégico das empresas estatais, os impactos que a imposição da substituição tributária trouxe em seus processos contábeis, 
financeiros, e tributários, bem como os controles sistemáticos de todos os compromissos advindos com a imposição de tal responsabilidade.

Tem também como conseqüência, demonstrar os custos incorridos com a admissão de novos empregados, desenvolvimento de sistemas, cumprimento das obrigações acessórias, e objetiva também, identificar os riscos que as empresas foram submetidas no caso de não cumprimento da legislação que rege o assunto.

Busca-se também utilizar as melhores praticas das empresas participantes, no melhoramento das rotinas de todas as demais. Este resultado deverá ser percebido quando da tabulação da pesquisa.

$\mathrm{Na}$ questão da parceria, melhorar o relacionamento entre as empresas, buscando um canal de comunicação que facilite as interações entre as administrações públicas, na medida em que algumas empresas possuem capilaridade na maioria das capitais brasileiras.

Em se tratando da informática, buscar entender os mecanismos de elaboração da Nota Fiscal de Serviços Eletrônica (NFS-e), ferramenta já usada por algumas administrações publicas, como forma de poder usar os dados, alimentando os sistemas internos das empresas participantes, e desta forma reduzir a digitação de informações já constantes das notas fiscais, o chamado processo de decodificação de dados.

Não se encontra literatura sobre o assunto. Há publicações esporádicas e genéricas, que não aprofundam sobre questões pontuais, tais como: custos, riscos, dificuldades de implantação, benefícios, enfim uma gama de problemas advindos com a imputação destas responsabilidades nas empresas, que não tendo como se movimentarem para "dizer não", tem assumido as determinações, incrementando nas áreas tributárias mais esta carga, sem um planejamento adequado para tal. 


\section{2 - Fundamentação Teórica}

Este trabalho foi estruturado em duas partes, da seguinte forma: primeiramente, faz-se um esboço sobre a relação comercial entre as empresas estatais e órgãos da administração pública municipal, estadual e federal e seus reflexos correlacionados nesta relação tais como: a sonegação fiscal e a guerra fiscal. Na segunda parte, faz-se referência ao processo da execução das atividades da substituição tributária com o fato gerador da obrigação principal, da obrigação acessória, do sujeito passivo da obrigação tributária, da substituição tributária, do imposto sobre serviços de qualquer natureza (ISSQN), do fato gerador do imposto sobre serviços (ISS), da lista de serviços obrigatórios, da base de cálculo do ISS, da análise da alíquota do ISS e da análise dos documentos fiscais geradores da substituição tributária.

\section{1 - Relação comercial entre as empresas estatais e órgãos da administração}

\section{pública}

Levando em consideração a relação comercial existente entre as empresas públicas objeto deste trabalho, e os entes da administração pública federal, estadual, municipal e do Distrito Federal, que em sua maioria são da administração direta, há uma questão jurídica a ser tratada, quando os documentos fiscais são encaminhados, e que por força de leis municipais a estes cabem a retenção, recolhimento e cumprimento das obrigações acessórias.

Neste particular, em se tratando da relação comercial entre empresas de governo e suas diversas entidades, há dificuldade de operação quanto à substituição tributária imposta ao pagador dos serviços, esbarrando em questão jurídica relacionada à imunidade recíproca.

Segundo NUNES (2006), desenvolve sobre o assunto o seguinte textos sobre a imunidade recíproca:

Questão polêmica, que tem colocado em lados opostos diferentes entes públicos, tem sido a imposição de regras de responsabilidade/substituição tributária entre si, especialmente no que tange ao Imposto Sobre Serviços de Qualquer Natureza (ISS). Diversos municípios exigem que órgãos da administração pública, federais ou estaduais, retenham o valor do ISS incidente sobre os serviços que lhes sejam prestados e o repasse a municipalidade. No entanto, em algumas situações, usando a imunidade recíproca como principal argumento, há quem defenda que estes órgãos devem se recusar a assumir tal encargo, assim como a pagar a multa imposta em função de tal omissão. Instaura-se, então, um autêntico conflito, em que, verdade seja dita, sofre a imensa maioria de municípios, a qual se encontra despojada do poder econômico que Estados e União detêm.

Os que se opõem á idéia de responsabilidade tributária imputada a órgão da administração pública e à conseqüente aplicabilidade de multas pelo seu inadimplemento, usam, em suma, um dos seguintes argumentos:

Uma interpretação sistemática do instituto da imunidade recíproca "parece levar, 
inevitavelmente, à conclusão de que, se União, Estados, Distrito Federal e Municípios estão impedidos de usarem o seu poder constitucional tributante para colocarem os demais entes políticos no polo passivo da relação tributária, como contribuinte originário, não poderão fazê-lo, também, pelo atalho da substituição tributária ou da responsabilidade tributária";

-Nem a União, nem os Estados, nem o Distrito Federal, nem os Municípios, podem ser tidos, no contexto da legislação dos tributos que incidam sobre o patrimônio, a renda e os serviços, como sujeitos passivos da relação tributária, ou como estando vinculados aos respectivos fatos geradores;

- não existe norma constitucional que permita venha a ser afastada ou restringida a imunidade recíproca, pelo subterfúgio da substituição tributária de contribuintes pelos entes políticos protegidos por aquela imunidade, sendo. assim frontalmente contrário à Constituição qualquer lei ou ato que vise impor essa condição aos referidos entes políticos;

- face o disposto nos Arts. 157, I, e 158, I, da Constituição da República Federativa do Brasil (CF), que tratam do imposto de renda retido na fonte por entes políticos beneficiários da imunidade recíproca, a norma legal não pretende equiparar essa atribuição/responsabilidade de reter e recolher o tributo à substituição legal tributária de que tratam o art. 128 , do $\mathrm{CTN}$, e o art. $150, \S 7^{\circ}$, da $\mathrm{CF} / 88$;

\section{2 - Sonegação fiscal}

A imposição das responsabilidades tributárias do prestador dos serviços, para o contratante dos serviços, além de dar mais garantias às prefeituras quanto ao cumprimento das obrigações tributárias principais e acessórias, também visa reduzir a sonegação e a guerra fiscal, na medida em que os prestadores de serviços só receberão de seus clientes, não mais o valor total da prestação dos serviços como era no passado, e sim o liquido dos documentos fiscais, que é alcançado pelo valor total da Nota Fiscal, deduzido dos valores dos impostos federais e do ISS, sendo estes repassados ao tesouro nacional e ao tesouro municipal respectivamente, quer seja por Documento de Arrecadação das Receitas Federais (DARF), ou Documento de Arrecadação das Receitas Municipais (DAR), conforme o destino dos recursos.

Segundo Harada (2007, p.414), a desconsideração de atos ou negócios jurídicos praticados pelo contribuinte só se legitima quando presentes a sonegação, a fraude ou o conluio definido, respectivamente, nos Arts. $71^{\circ}, 72^{\circ}$ e $73^{\circ}$ da Lei $n^{\circ} 4.502$ (BRASIL, 1964), nos seguintes termos:

Art. $71^{\circ}$. Sonegação é toda a ação ou omissão dolosa tendente a impedir ou retardar, total ou parcialmente, o conhecimento por parte da autoridade fazendária:

I - da ocorrência do fato gerador da obrigação tributária principal, sua natureza ou circunstâncias materiais;

II - das condições pessoais do contribuinte, suscetíveis de afetar a obrigação tributária principal ou o crédito tributário correspondente.

Art. $72^{\circ}$. Fraude é toda ação ou omissão dolosa tendente a impedir ou retardar, total ou parcialmente, a ocorrência do gato gerador da obrigação tributária principal, ou a excluir ou 
modificar as suas características essenciais, de modo a reduzir o montante do imposto devido, ou a evitar ou diferir o seu pagamento.

> Art. $73^{\circ}$. Conluio é o ajuste doloso entre duas ou mais pessoas naturais ou jurídicas, visando qualquer dos efeitos referidos nos Arts. 71 e 72. Como se verifica, nas três hipóteses há conduta dolosa do contribuinte visando à supressão total ou parcial do tributo devido ou à postergação de seu pagamento. Os atos jurídicos praticados pelo contribuinte, com a finalidade de trilhar o caminho menos oneroso, em termos de encargo tributário, são legítimos, legais e constitucionais. Nada têm a ver com as condutas tipificadas nos dispositivos retromencionados.

A Lei $\mathrm{n}^{\circ}$ 8.137, de 27 de Dezembro de 1990, (BRASIL, 1990), no inciso II, do Art. $2^{\text {o }}$, classifica como crime contra a ordem tributária, o não recolhimento, no prazo legal, do valor do tributo ou da contribuição social, descontado ou cobrado, na qualidade de sujeito passivo de obrigação e que deveria recolher aos cofres públicos.

\section{3 - Guerra fiscal}

Martins (2007) discorre sobre o conceito de "guerra fiscal", afirmando que os municípios têm feito de tudo para aumentar a arrecadação, e assim tenta imputar aos prestadores de serviços não domiciliados no âmbito do território do município a responsabilidade pelo recolhimento do ISSQN no local da prestação dos serviços. Sobre a guerra fiscal relacionada ao ISS, no texto publicado, faz as seguintes considerações:

A guerra fiscal é um desvio da intenção do legislador, e favorece os administradores públicos que burlam a lei e que adotam interpretações tortuosas, até mesmo inescrupulosas, da legislação em vigor. No caso da guerra fiscal entre municípios o campo de batalha se encontra no ISS (Imposto sobre Serviços de Qualquer Natureza).

Hoje, municípios enquadrados em três tipos de situação reivindicam para si a arrecadação do ISS. Em primeiro lugar, os municípios onde ocorre a produção dos serviços prestados; em segundo, os municípios onde os serviços produzidos são disponibilizados ao tomador dos mesmos; e a guerra fiscal produziu um terceiro tipo de município, que reivindica a receita do ISS por abrigarem em seu território as sedes administrativas das empresas prestadoras dos serviços, ainda que nele não estejam localizados, de fato, nem o estabelecimento produtor nem o estabelecimento consumidor.

Conceitualmente, há justificativas para que tanto os municípios produtores, como os municípios consumidores busquem arrecadar ISS. Um disponibiliza infra-estrutura e meios para produção dos serviços; outro, paga por eles. O mais justo seria que pudessem compartilhar daquela receita, o que infelizmente é inviável por força da onerosa operacionalização deste procedimento.

Corsários - Mas nada justifica que, com a guerra fiscal, surja um terceiro município, que não é onerado pela produção, nem pelos gastos do consumo, e que desvie para si toda a arrecadação. A guerra fiscal do ISS cria a figura de um município-corsário, que simplesmente absorve a contrapartida tributária da produção e do consumo, sem nada contribuir para tanto.

A origem do conflito encontra-se nas diferentes interpretações dadas ao termo "estabelecimento prestador" dos serviços abrangidos pela cobrança do ISS, expressão constante do Decreto Lei n ${ }^{0} 406$ (BRASIL, 1968), que deu início à efetiva cobrança desse tributo. 
Anteriormente, apesar de o tributo constar das Cartas Magnas de 1946 (BRASIL, 1967) e de 1967 (BRASIL, 1967), bem como do Código Tributário Nacional, Lei n ${ }^{\circ}$ 5.172 (BRASIL, 1966), a lista de serviços tributados continha apenas três itens.

Com o Decreto $\mathrm{n}^{\circ} 406$ (BRASIL, 1968), a lista foi ampliada para 29 serviços, e houve uma primeira tentativa de disciplinamento e de definição das normas gerais de funcionamento do ISS.

Dizia o Decreto ${ }^{\circ} 406$ (BRASIL, 1968), em seu artigo 12, que "considera-se local da prestação do serviço" (e conseqüente o município detentor do direito de tributar a operação) "o do estabelecimento prestador ou, na falta de estabelecimento, o do domicílio do prestador". Logo em seguida, abriu-se a primeira exceção, aplicada no caso da construção civil, onde o tributo é devido no "local onde se efetuar a prestação".

O ISS sofreu modificações e ampliação em sua lista de serviços através do Decreto Lei n o 834 (BRASIL, 1969) (que ampliou a lista para 66 itens), da Lei Complementar $\mathrm{n}^{\circ} 56$ (BRASIL, 1987) (que ampliou a lista novamente para uma centena de itens), da Emenda 1/69 e da Lei Complementar $n^{\circ} 100$ (BRASIL, 1999) (que incluiu pedágios), passando pela Carta Magna de 1988.

Mas foi a Lei Complementar n ${ }^{\circ} 116$ (BRASIL, 2003) que efetivamente atualizou a legislação e a regulamentação do ISS. Ampliou a lista de serviços para 193 itens, e adicionou 20 novos tipos de serviços que, a exemplo da construção civil, passaram a ser tributados no local da prestação dos serviços, ou seja, no local do tomador dos serviços.

A guerra fiscal do ISS já havia surgido anteriormente, a partir da interpretação de que o termo "estabelecimento prestador" dos serviços significa sede, matriz ou escritório central da empresa prestadora de serviços. Neste sentido, vários municípios passaram a oferecer alíquotas reduzidas, ou redução de base de cálculo, para as empresas que se "instalassem" em seus respectivos territórios, e assim passariam a recolher o ISS mesmo que o "estabelecimento prestador" estivesse em outros municípios onde os serviços eram efetivamente disponibilizados.

Surgiram duas situações. Uma primeira, de flagrante ilegalidade, ocorre no caso dos municípios que, mesmo após a promulgação da Emenda Constitucional n ${ }^{\circ} 37$ (BRASIL, 2002) (que estabeleceu piso de $2 \%$ na alíquota do ISS), continuaram a oferecer alíquotas inferiores àquele patamar. Alíquotas abaixo do piso ferem a Constituição, que proíbe em seu artigo 88 das disposições transitórias a "concessão de isenções, incentivos e benefícios fiscais, que resulte, direta ou indiretamente, na redução da alíquota mínima estabelecida..." Mesmo que o "estabelecimento prestador" esteja efetivamente localizado no município, o mesmo não pode praticar renúncia fiscal, tributando-o a menor do que $2 \%$, seja em termos de sua alíquota nominal, sejam em termos de redução de sua base de cálculo (definida como o preço cheio dos serviços prestados).

Esperteza - A segunda situação é uma fraude evidente, escorada em uma interpretação equivocada da lei. Empresas passaram a instalar-se apenas "no papel" em paraísos fiscais, mantendo nessas localidades apenas uma sede de fachada, uma caixa postal, ou um endereço formal, mas não possuindo no local qualquer "estabelecimento prestador" de serviços. Há casos notórios de empresas cujos endereços de suas sedes localizavam-se em prédio da própria prefeitura, em hotéis de empresas, e até mesmo em cemitérios públicos. Estes fatos foram recentemente denunciados pela revista Veja em sua edição de 11 de janeiro de 2006.

A primeira situação, de alíquota efetiva abaixo de $2 \%$, é inquestionavelmente ilegal, e surpreende que nenhuma providência tenha sido adotada pelas autoridades públicas. $\mathrm{O}$ fato é que dificuldades jurídicas têm sancionado o comportamento predatório de municípios que praticam a guerra fiscal, em detrimento daqueles que respeitam a legislação em vigor.

Já na segunda situação, a indefinição interpretativa do que seja "estabelecimento prestador" de serviços explica o comportamento de empresas que verdadeiramente se deslocam para os municípios de baixa tributação. Mas não deve haver a mesma tolerância com aqueles que fraudam a lei, e criam sedes de fachada para auferirem, em ambos os casos, alíquotas ilegalmente reduzidas.

A Lei Complementar $n^{\circ} 116$ (BRASIL, 2003) busca esclarecer o que é "estabelecimento prestador" de serviços. Cumpre reproduzir seus artigos $3^{\circ}$ e $4^{\circ}$ : 
"Art. $3^{\circ} \mathrm{O}$ serviço considera-se prestado e o imposto devido no local do estabelecimento prestador"...; e

"Art. $4^{\circ}$ Considera-se estabelecimento prestador o local onde o contribuinte desenvolva a atividade de prestar serviços, de modo permanente ou temporário, e que configure unidade econômica ou profissional, sendo irrelevantes para caracterizá-lo as denominações de sede, filial, agências, posto de atendimento, sucursal, escritório de representação ou contato ou quaisquer outras que venham a ser utilizadas".

Mesmo com os esclarecimentos cabais da Lei Complementar $n^{\circ} 116$ (BRASIL, 2003), a guerra fiscal continua correndo solta. É neste contexto que surge a Lei ${ }^{\circ}{ }^{\circ}$ 14.042 (BRASIL, 2005) na cidade de São Paulo.

Exigência - Procurando dar conseqüência prática aos ditames da Lei Complementar $\mathrm{n}^{\circ} 116$ (BRASIL, 2003), o município de São Paulo passou a exigir que prestadores de serviços de que emitam notas físcais autorizadas por outros municípios se cadastrem e comprovem que seu "estabelecimento prestador" situa-se efetivamente fora de São Paulo. Caso a comprovação não seja satisfatória (exige-se documentação, provas de gastos em telefonia e energia, contratação de mão-de-obra e fatos que demonstrem que a empresa funciona efetivamente no local), o tomador de serviços torna-se responsável pela retenção na fonte do $1 \mathrm{SS}$ e por seu recolhimento aos cofres paulistanos. Tal lei vem sendo questionada na Justiça. Mas independentemente do resultado final, todos sairão perdendo.

Cabe lembrar que as empresas cujo cadastramento em São Paulo não seja autorizado sofrerão retenção do ISS na fonte. O grande problema que surge para elas, no entanto, é que poderão ser cobradas novamente no município onde supostamente estejam formalmente instaladas. Ademais, os municípios passarão a sofrer de grande insegurança quanto ao recolhimento do ISS, pois o método de aferição do local efetivo do estabelecimento é arbitrário, e poderá ser usado de tal forma a captar o máximo possível de ISS para o município que faz a exigência de cadastramento. Inevitavelmente, haverá retaliação de outros municípios, que passarão a fazer as mesmas exigências. O Judiciário receberá uma enxurrada de ações, e não seria difícil prever que em breve os empresários, entre o mar e o rochedo, acabem depositando em juízo o ISS, até que a questão acerca do destino do tributo seja dirimida.

Em resumo, da forma como a situação do ISS está delineada, os conflitos em breve se tornarão um dos maiores focos de contenciosos tributários do país, com prejuízos evidentes para todos. Um jogo de soma nitidamente negativa em longo prazo, mesmo para aqueles municípios que hoje auferem vantagens momentâneas. Cumpre dizer que mesmo as empresas que se beneficiam deste expediente poderão no futuro ser consideradas co-responsáveis, e acabar sendo acusadas de receberem benefícios manifestamente ilegais e, portanto, obrigadas a restituir as vantagens indevidas que auferiram.

A solução para o problema seria seguir a tendência em direção ao principio do destino, ou seja, considerar-se que o imposto é devido no local do estabelecimento do tomador do serviço (do consumidor).

Inicialmente, com a construção civil, Decreto $\mathrm{n}^{\circ} 406$ (BRASIL, 1968), a transferência da arrecadação para o município do tomador dos serviços foi estendida aos pedágios, Lei Complementar $n^{\circ} 100$ (BRASIL, 1999) e depois para 20 outros setores, Lei Complementar $n^{\circ} 116$ (BRASIL, 2003). Aliás, uma correta interpretação da legislação do ISS implicaria entender que o "estabelecimento de prestação" é o local onde o serviço é executado e disponibilizado ao cliente final, e nesse caso na imensa maioria das vezes o local do "estabelecimento do prestador" coincidirá com o do "estabelecimento do tomador". Nesse caso, mesmo que a sede administrativa, ou o endereço formal, de uma empresa de serviços esteja em outro município, o recolhimento do ISS deveria ser no município onde ocorre a atividade produtora e consumidora dos serviços.

Nesse sentido, a solução para o angustiante problema do ISS seria a continuidade desta tendência à sua conseqüência lógica. Em outras palavras, há que se inverter a legislação. O que hoje é a exceção (tributo devido no local do estabelecimento de tomador do serviço, no destino) passaria a ser a regra; e a regra (tributo devido no local do estabelecimento prestador do serviço, na origem) passaria a ser a exceção.

Esta proposta tem algumas vantagens. Primeiramente, eliminaria as dúvidas e 
incertezas oriundas das diferentes interpretações sobre o local de recolhimento do tributo. Ocorreria sempre no local do estabelecimento do tomador, onde o serviço foi concretamente disponibilizado, independentemente de definições formais acerca do domicilio legal das empresas prestadora e tomadora dos serviços.

Em segundo lugar permitiria alterar o regime de arrecadação do tributo, tornando a retenção na fonte uma obrigação do tomador do serviço, que o recolheria no município de funcionamento de seu estabelecimento. Ao fazer o tomador do serviço um contribuinte substituto do ISS se estará seguindo uma tendência já existente na legislação tributária brasileira, como, por exemplo, ocorre com o imposto de renda, com as contribuições previdenciárias, e com o próprio ISS na construção civil. A fiscalização de cada município ficará restrita às empresas que operam dentro de suas respectivas áreas geográficas, eliminando questões de competência como vêm sendo argüidas no entendimento da Lei $n^{\circ} 14.042$ (BRASIL, 2005) da cidade de São Paulo.

Em terceiro lugar, tal procedimento simplifica a legislação, além de automatizar e uniformizar os procedimentos de recolhimento do tributo. E em quarto lugar, a solução aqui proposta elimina a presença dos municípios-corsários, e cria uma situação de maior justiça social $\mathrm{O}$ município produtor se beneficia da renda e dos empregos gerados pela prestação dos serviços; e o município consumidor fica com a receita tributária. Uma situação aceitável do ponto de vista de eqüidade.

Finalmente, este novo regime de tributação do ISS tem um subproduto interessante: permitiria a eliminação do piso de $2 \%$ na alíquota, pois o município que deseja implantar uma política de baixa tributação poderia fazê-lo sem com isto induzir maciça migração de empresas em busca de reduções tributárias. A migração de empresas consumidoras de serviços em busca de baixo ISS poderá ocorrer em setores altamente intensivos em insumos terciários, mas com certeza terá amplitude reduzida. Este novo regime permitiria, portanto, uma saudável competição tributária, em lugar da predatória guerra fiscal hoje instalada no país.

Segundo Oliveira (2003), na região metropolitana de São Paulo, quando o município de Barueri passou a oferecer os benefícios fiscais aos prestadores de serviços de informática, praticamente, todos os prestadores deste tipo de serviço passaram a ter endereço no município, onde concentravam seus faturamentos. Evidentemente que na grande maioria dos serviços prestados, estes eram realizados no município de São Paulo.

Ainda conforme Oliveira, outras empresas de prestação de serviços, tais como segurança; limpeza e conservação; recrutamento e seleção; cessão de mão de obra, aproveitando dos benefícios fiscais praticados por municípios adjacentes às grandes cidades, transferia seus endereços para aqueles municípios, criando os citados estabelecimentos "de fachada". Com a Lei Complementar $n^{\circ} 116$ (BRASIL, 2003), para estes casos, o legislador tenta dar um fim à guerra fiscal, estabelecendo que o tomador dos serviços faça a retenção e o recolhimento do ISSQN.

Deixando de lado as questões polêmicas entre entes políticos distintos, sonegação e guerra fiscal, vamos ao desenvolvimento do trabalho proposto, na medida em que ao longo dos registros vamos ter oportunidade de verificar se entre as empresas e suas relações comerciais com os órgãos da administração pública direta está havendo dificuldades quanto ao cumprimento das obrigações principais e assessorias. 


\section{4 - Fato gerador da obrigação principal}

O Código Tributário Nacional (BRASIL, 1966), em seu Art. $114^{\circ}$ estabelece que "Fato gerador da obrigação principal é a situação definida em lei como necessária e suficiente à sua ocorrência." Assim, caracteriza-se fato gerador, para o ISSQN, a efetiva prestação dos serviços, sendo necessário, portanto que, para ter sustentabilidade legal para imputação de responsabilidades, que haja previsão em lei.

Segundo Pêgas (2007, p. 47), a efetiva prestação de serviços poderá acarretar na obrigação do cumprimento do recolhimento aos cofres públicos dos recursos monetários devidos, e neste caso, caracteriza, conforme a lei, uma obrigação principal, ou caso não haja o cumprimento de uma obrigação pecuniária, uma obrigação acessória, que nada mais é do que escriturar um livro fiscal ou emitir uma declaração, enviando-a posteriormente ao agente público

\section{5 - Fato gerador da obrigação acessória}

O Art. $115^{\circ}$ do Código Tributário Nacional (BRASIL, 1966) define que "Fato gerador da obrigação acessória é qualquer situação que, na forma da legislação aplicável, impõe a prática ou a abstenção de ato que não configure obrigação principal."

Pode-se depreender, portanto, que obrigação acessória, é aquela onde, por previsão legal, os agentes públicos possam verificar a correta aplicação da obrigação principal, servindo desta forma de meio pelo qual se possa ter a certeza de que ao se constatar a ocorrência do fato gerador principal, este esteja relatado de forma escritural, nas obrigações acessórias.

No que se refere ao Art. $115^{\circ}$ do CTN, (BRASIL, 1966), Coelho faz a seguinte crítica:

\footnotetext{
O artigo não possui densidade. Vimos que as chamadas obrigações acessórias não possuem "fato gerador"; decorrem de prescrições legislativas imperativas: "emita notas fiscais", "declare rendas e bens" etc. À impropriedade redacional é sem par. Diz-se que o fato gerador da obrigação acessória é "qualquer situação" que, na forma de "legislação aplicável", impõe a "pratica ou abstenção de ato". Outra maneira de prescrever deveres de fazer e não fazer por força de lei. Cabe apenas reafirmar que a legislação a que se refere o artigo somente pode ser coleção de leis em sentido formal e material. (COELHO, 2001, p. 583).
}

Na Revista Exame, deste mês de março de 2009, Pimenta (2009, p. 43) publicou artigo intitulado "Seis passos para sair do caos", onde relata: 


\begin{abstract}
Além do monstruoso peso da carga fiscal, outra grande dor de cabeça das empresas brasileiras é lidar com os emaranhados burocráticos que cercam as tarefas de pagar os tributos e atender às exigências dos órgãos governamentais. Entre elas estão às chamadas obrigações acessórias, o que no jargão técnico significa provar ao Fisco que o pagamento dos tributos está em dia. Existem nada menos que 97 dessas obrigações, entre carimbos, rubricas e livros fiscais, além da trivial necessidade de que todas as cópias de documentos tenham de passar por cartórios para ser autenticadas.
\end{abstract}

Numa das dicas propostas por Pimenta para reduzir a carga burocrática impostas pela legislação diz respeito à "Redução de Exigências" onde poderia ser extintas a necessidade de apresentação de cópias autenticadas, deixando de lado o conceito de que o contribuinte é, antes de tudo, suspeito. Assim haveria ganho em economia de tempo e redução dos custos que tais exigências trazem às empresas. $\mathrm{O}$ entendimento é que esta possibilidade se torne viável no curto prazo, na medida em que a implantação do Sistema Público de Escrituração Digital (SPED), que esta sendo desenvolvido pelo Serpro, a pedido da Secretaria da Receita Federal do Brasil (SRFB), traz em seu bojo a drástica redução da impressão de livros fiscais, substituindo-os por arquivos magnéticos, devendo também reduzir a burocracia, pois é também um dos focos do novo sistema, a implantação da Nota Fiscal Eletrônica (NF-e).

\title{
2.6 - Sujeito passivo da obrigação tributária
}

O Art. $121^{\circ}$ do Código Tributário Nacional, (BRASIL, 1966), traz em seu bojo, a conceituação do que vem a ser sujeito passivo da obrigação tributária:

Art. $121^{\circ}$ - Sujeito passivo da obrigação principal é a pessoa obrigada ao pagamento de tributo ou penalidade pecuniária.

○ Parágrafo único. O sujeito passivo da obrigação principal diz-se:

- I - contribuinte, quando tenha relação pessoal e direta com a situação que constitua o respectivo fato gerador;

- II - responsável, quando, sem revestir a condição de contribuinte, sua obrigação de disposição expressa de lei. (BRASIL, 1966).

Segundo Coelho (2001, p. 591), “o sujeito passivo é denominado pelo CTN de contribuinte quando realiza, ele próprio, o fato gerador da obrigação, e de responsável quando, não realizando o fato gerador da obrigação, a lei lhe imputa o dever de satisfazer o crédito tributário em prol do sujeito ativo.” 
Conforme, Melo (2000) conclui que o contribuinte ao realizar fato gerador do imposto, passa a ter seu patrimônio comprometido em benefício do sujeito ativo.

Portanto, como sujeito passivo do ISS, teremos:

1 - Contribuinte

O prestador dos Serviços; e

2 - Responsável

Aquele que recebe a atribuição por disposição expressa da Lei, de realizar o recolhimento aos cofres públicos, tendo este realizado ou não a retenção do respectivo imposto.

\section{7 - Substituição Tributária}

Por substituição tributária entende-se a transferência da responsabilidade de pagar o imposto do prestador dos serviços (contribuinte), para o tomador dos serviços, independentemente deste ser considerado imune ou isento, sendo esta transferência de responsabilidade considerada como substituição tributária passiva Art. $128^{\circ}$ do CTN.

Melo (2000) considera que a substituição pressupõe a transferência legal de responsabilidade por obrigação de terceiro que possuí vinculo direto com o verdadeiro contribuinte.

Há uma confusão nos instrumentos legais das prefeituras, que não conseguem distinguir corretamente as responsabilidades tributárias quando relacionadas à substituição. Harada assim descreve estas confusões:

Todas as legislações municipais confundem a figura do responsável, em que se opera a substituição do sujeito passivo, por expressa disposição legal, observado o disposto no art. $128^{\circ}$ do $\mathrm{CTN}$, com o regime de retenção na fonte, que nada tem a ver com a substituição tributária. Nesta, a obrigação do prestador do serviço desaparece substituída que fica pelo do tomador do serviço, o qual passa a pagar o imposto próprio, apesar de não ter praticado o fato jurídico tributável. No regime de retenção, o tomador promove o pagamento de imposto alheio, tanto é que o nãorecolhimento do tributo retido configura crime de apropriação indébita (HARADA, 2006, p. 472).

Já Coelho, nos faz refletir ainda mais sobre o artigo $128^{\circ}$ :

O Art. $128^{\circ}$, quando cuida da responsabilidade por substituição, põe requisitos inarredáveis, os quais devem ser necessariamente observados pelos legisladores das 
três ordens de governo que convivem na Federação brasileira. Tratemos o tema, entretanto, com a minúcia e a profundidade que lhe são devidas. É preciso distinguir bem os casos de responsabilidade direta e indireta, que Rubens Gomes Souza propagou em toda a doutrina pátria. O notável Mestre de todos os tributaristas brasileiros, cuja memória cultuou com respeito e admiração, dividia as hipóteses de "sujeição passiva indireta", em tema de tributação, em duas chaves:

Sujeição passiva indireta

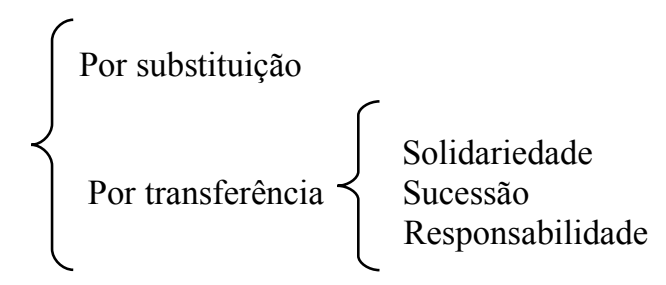

Dizia o Mestre: a transferência “ocorre quando a obrigação tributária depois de tiver surgido contra uma pessoa determinada (que seria o sujeito passivo direto), entretanto, em virtude de um fato posterior, transfere-se para outra pessoa diferente..."

E a substituição "ocorre quando em virtude de uma disposição expressa de lei a obrigação tributária surge desde logo contra uma pessoa diferente daquela que esteja em relação econômica com o ato, o fato ou o negócio tributado. Neste caso é a própria lei que substitui o sujeito passivo direto por outro indireto". (COELHO, 2001, p. 598-599).

No Governo do Distrito Federal, a substituição tributária está amparada pelo Decreto $\mathrm{n}^{\mathrm{o}}$ 25.508 (BRASIL, 2005), em seu Art. $8^{\circ}$, na subseção I, que trata da Responsabilidade por Substituição Tributária.

Segundo Júnior (2004), a Prefeitura Municipal de Curitiba, por intermédio da Lei Complementar $n^{\circ} 48$, (BRASIL, 2003), introduziu alterações, aplicando a retenção obrigatória em idêntica lista ao do art. $3^{\circ}$ da Lei Complementar $n^{\circ} 116$ (BRASIL, 2003), mantendo as demais hipóteses de retenção anteriormente existentes, na forma dos artigos $7^{\circ}$ e $8^{\circ}$-A da Lei Complementar $n^{\circ} 40$ (BRASIL, 2001), sempre levando em consideração o fato de o imposto ser de sua efetiva competência.

Nogueira (2006) esclarece que o responsável tributário, também chamado de substituto tributário, é o responsável tanto pela obrigação principal (a do recolhimento), quanto pela acessória (declarações), competindo-lhe praticar todos os deveres instrumentais no interesse da administração fazendária. Desta forma o substituto tributário deverá realizar o recolhimento do imposto retido. Quando não fizer a retenção (obrigação acessória), passa a dever o imposto oriundo da obrigação de reter, que é convertida em principal, e assim está se transforma em uma obrigação pecuniária. 


\title{
2.8 - Imposto sobre serviços de qualquer natureza (ISSQN)
}

Cabe aos municípios e ao Distrito Federal instituir o Imposto sobre serviços de qualquer natureza, estando tal competência amparada pela Constituição de 1988, em seu artigo 156, Inciso III.

Segundo Melo (2000, p. 30), "o fato da Constituição não ter conceituado "serviço" para fins de incidência do ISS - não pode causar nenhum problema para o operador do direito, uma vez que o texto constitucional contém materialidades - também adstritas às obrigações de "dar" e de "fazer" - que permitem separar os respectivos campos de incidência tributária."

Conforme Oliveira (2006) prega que a enorme quantidade de tributos de responsabilidade dos diversos níveis de governo promoveu um crescimento desordenado dos tributos lançados nos últimos anos, provocando constantes recordes de arrecadação, aumentando de um lado a indústria da arrecadação e fiscalização e de outro, os custos necessários a sua apuração e recolhimento, sem contar as possibilidades de ocorrência de sonegação.

Segundo Oliveira, os empresários estão onerados pelo excesso de tributos em vigor, esclarece ainda que:

\begin{abstract}
Essa situação tem causado forte campanha em favor da mudança do Sistema Tributário Nacional, que passa por uma revisão de texto constitucional. Algumas sugestões primam pela radical idade, como é o caso do imposto único. Outras, mais racionais, buscam aproximar o Brasil das nações do Primeiro Mundo, reduzindo a quantidade de tributos, mas mantendo na essência o que hoje se realiza, ou seja, a tributação sobre a renda, o consumo e a propriedade, e simplificando o processo de arrecadação. (Oliveira, 2006, p. 26)
\end{abstract}

\section{9 - Fato gerador do ISS}

A Lei complementar $\mathrm{n}^{\mathrm{o}} 116$ (BRASIL, 2003), estabelece em seu artigo $1^{\mathrm{o}}$, que "o Imposto Sobre Serviços de Qualquer Natureza, de competência dos Municípios e do Distrito Federal, tem como fato gerador a prestação de serviços constantes da lista anexa, ainda que esses não se constituam como atividade preponderante do prestador.”

Sobre o artigo citado acima, Cezaroti, faz as seguintes considerações:

A previsão do parágrafo $1^{\circ}$ do artigo $1^{\circ}$ da Lei Complementar $n^{\circ} 116$ (BRASIL, 2003) é de difícil harmonização com o conjunto da legislação, porque, nas hipóteses de serviços prestados no exterior ou cuja prestação tenha início no exterior, é a fruição que ocorrerá no Brasil, mas, conforme demonstrado anteriormente, o 
legislador constituinte não concedeu ao legislador complementar para tributar a fruição dos serviços.

A incidência do ISS no local do estabelecimento do tomador ou intermediário do serviço ou, na falta de estabelecimento, no local onde estiverem domiciliados confirma o entendimento de que o legislador complementar pretendeu tributar a fruição de serviços.

Não bastasse a ausência de competência para tributar a fruição do serviço, as leis municipais que instituírem o ISS em cada município não têm efeitos fora de seu território, por isso não há como imaginar um município da Grande São Paulo pretender tributar um serviço prestado na Europa, ainda que nele esteja domiciliado quem fruiu do serviço. Além disso, os municípios não têm competência para fiscalizar a prestação de serviços ocorrida fora de seu território, o que inviabiliza esta incidência tributária. (CEZAROTI, 2004, p. 50).

Eventualmente, o profissional da área analise tributário encontra dificuldades em definir se o imposto refere-se à prestação de serviços, ou a circulação de mercadorias.

Machado (2004) esclarece:

O contribuinte que realizar, simultaneamente, atividade definidas como fato gerador de cada um dos dois tributos, deve segregar as operações que ensejarem a incidência do ICMS e as que ensejarem a incidência do ISS, e oferecê-las à tributação de acordo.

O Superior Tribunal Federal (STF) aplicou esse raciocínio em decisão que envolvia a incidência de ISS sobre os serviços paralelos prestados pelas empresas de telecomunições, tais como locação de aparelhos, mesas, terminais, colocação e retirada de troncos. Nesta decisão, o STF concluiu que a incidência do imposto sobre comunicações (à época dos fatos, de competência da União) não impedia a incidência do ISS sobre as atividades paralelas. (Machado, 2004, p. 184).

\subsection{0 - Lista de serviços}

A lista de anexa à Lei Complementar $n^{\circ} 116$ (BRASIL, 2003), relaciona todas as possibilidades de prestação de serviços de competência dos municípios. A citada lista é dividida em itens e subitens, facilitando o entendimento e a pesquisa, fato que não ocorria nas listas anteriores. A lista é composta de aproximadamente 230 serviços, distribuídos em 40 itens.

\subsection{1 - Base de calculo do ISS}

Segundo Harada (2006), depois de identificado o fato gerador, estabelecido o sujeito passivo e determinada a matéria tributável, há que se calcular o montante do tributo devido aplicando-se a alíquota sobre a base de calculo.

Conforme o Art. $7^{\circ}$ da Lei Complementar $n^{\circ} 116$ (BRASIL, 2003), a base e cálculo do imposto é o preço do serviço. 


\subsection{2 - Alíquotas do ISS.}

As alíquotas do ISS são fixadas pelos municípios, não podendo ser superior a $5 \%$ (Cinco por cento), pois assim estabelece a Lei Complementar $n^{\circ} 116$ (BRASIL, 2003), em seu artigo $8^{\circ}$, inciso II.

A tributação é fixa para os profissionais liberais, e proporcionais para as empresas que prestam serviços.

Segundo Sabbag (2005), enquanto não for editada lei complementar, conforme determina a Constituição (BRASIL, 1988) no inciso I, do parágrafo $3^{\circ}$, do artigo 156, instituindo a alíquota mínima, em regra está será de $2 \%$, e a máxima de $5 \%$.

As empresas que possuam filiais em outras cidades precisam conhecer as legislações municipais, além daquela do município onde estão instaladas, a fim de classificar corretamente as alíquotas do imposto incidente sobre a prestação dos serviços. Isto implica dizer que os departamentos tributários das mesmas são obrigados a estarem sempre preparados para disseminar entre os empregados envolvidos no processo de avaliação da documentação os conhecimentos necessários à correta aplicação das normas legais.

\subsection{3 - Análise dos documentos fiscais}

Nesta etapa os documentos fiscais são analisados por cada item que os compõem para identificar o fato gerador e das demais obrigações principal e acessória, relativo aos serviços prestados na relação comercial.

\subsection{1 - Conferência prévia dos documentos fiscais}

O responsável pelo contrato deverá efetuar a conferência prévia dos dados constantes dos documentos fiscais, por ocasião de seus recebimentos, atestando que as condições da contratação foram plenamente atendidas, em consonância com as determinações contratuais.

Nos procedimentos de verificação dos dados constantes nos documentos fiscais, o profissional responsável pela fase da liquidação da despesa deverá conferir:

- Se o emitente do documento fiscal corresponde, contratualmente, com a empresa responsável pela execução do serviço e/ou fornecedora do bem; 
- Se a data de emissão do documento fiscal corresponde com a data da efetiva prestação do serviço pela empresa contratada;

- Se o destinatário do documento fiscal corresponde, contratualmente, com a identificação cadastral do estabelecimento da empresa no qual ocorrerá à execução do serviço pela empresa contratada;

- Se a natureza da operação corresponde contratualmente, com descrição do serviço executado pela empresa contratada, em consonância com a legislação pertinente.

Além das providências anteriormente descritas, caberá ao responsável, devolver o documento Fiscal, quando do seu recebimento, para regularização ou substituição, se verificar as seguintes situações:

- se o valor discriminado na Nota Fiscal divergir da soma dos itens faturados, que deve corresponder ao preço dos serviços efetivamente prestados, em consonância com o documento Contratual;

- se a natureza da descrição do serviço prestado divergir do contrato, inclusive se inviabilizar a identificação para o cumprimento da obrigação fiscal; e

- $\quad$ se o documento fiscal específico, correspondente a contratação de serviços com atividades em condições especiais, prejudiciais à saúde ou à integridade física decorrente de cessão de mão-de-obra ou empreitada ou de cooperados, por meio de cooperativa de trabalho, divergir do instrumento contratual, bem como do Perfil Profissiográfico Previdenciário (PPP) e inviabilizar a identificação para o cumprimento da obrigação fiscal.

\subsection{2 - Análise fiscal dos documentos fiscais}

Cabe ao responsável pela análise tributária:

- realizar a conferência dos cálculos e demais condicionantes do documento fiscal, para o cumprimento legal das obrigações principais e acessórias vigentes; 
- efetuar a conferência do documento, inclusive os destaques das contribuições do INSS sobre Cessão de mão-de-obra ou Empreitada, ICMS, ISSQN, IRRF, IRPJ, COFINS, CSLL, PIS/PASEP, bem como outros Impostos Federais e Contribuições; e

- verificar se as deduções e reduções da base de cálculo e respectivas comprovações fiscais para a apuração dos impostos, estão de acordo com a legislação pertinente.

\subsection{4 - Retenção na fonte dos tributos e o recolhimento}

Vencidas todas as etapas acima, e ainda: adequação dos serviços à lista de serviços da Lei Complementar n ${ }^{\circ} 116$ (BRASIL, 2003); identificação da base de cálculo do imposto; percentual a ser aplicado sobre a base de cálculo; o sujeito ativo ao qual deve ser repassado o tributo torna-se necessário realizar a retenção na fonte do valor do ISS. Este é o momento mais importante e mais complexo, pois o tomador de serviços, devidamente qualificado pela municipalidade, deve em seu processo contábil, reconhecer o crédito tributário, devendo no momento do pagamento ao fornecedor, e no prazo estabelecido pela legislação do município, realizar o recolhimento, e, caso não o faça, será responsabilizado por apropriação indébita, que além dos castigos da lei, ainda será penalizado com multa e correção monetária pelo não cumprimento dos preceitos legais.

Não obstante o reconhecimento e recolhimento do imposto, o tomador dos serviços, ainda terá que apresentar ao prestador dos serviços, declaração de que os valores foram devidamente recolhidos, e também à prefeitura, que na maioria já conta com serviços informatizados, informações quanto aos documentos fiscais, valores das prestações de serviços e as respectivas retenções.

Os responsáveis pela classificação dos documentos fiscais devem se revestir de praticas seguras quanto à verificação dos direitos, tanto do prestador dos serviços, quanto das prefeituras, evitando que cálculos incorretos elevem ou diminuam o valor a ser pago, ou recolhido, pois caso haja erro, com certeza alguém será prejudicado. Se o valor tiver sido recolhido à maior, o prestador de serviços terá que movimentar processo administrativo junto à secretaria do município beneficiário do imposto, solicitando ressarcimento, que como já sabemos é de demorada solução. Caso o valor seja retido a menor, o fornecedor deverá enviar a diferença ao cliente para que este após os cálculos das multas e encargos moratórios repasse o 
valor ao município. Neste caso, também sabemos quais as repercussões o assunto causa dentro das áreas responsáveis pelo acompanhamento e controle dos riscos da função. Com certeza alguém será penalizado a ressarcir os danos causados, e na melhor das hipóteses ainda levará uma advertência pelo prejuízo causado.

Há que se lembrar que o fisco pode exigir do substituto, o pagamento do imposto, caso este não venha a ser recolhido, ou recolhido a menor, pois os substitutos tributários estão obrigados ao recolhimento do imposto. Portanto o substituto é obrigado a reter e recolher o imposto, sendo que caso tenha realizado a retenção e não o tenha repassado aos cofres públicos municipais, será considerado apropriação indébita, levando o administrador a responsabilização por tal fato, no rigor da Lei, ato sujeito a penalidades administrativas, civis e criminais.

Como no caso da substituição tributária o responsável pelo recolhimento passa a ser o tomador dos serviços, este também é o responsável pelo imposto, pela multa e acréscimos legais, todos vinculados à hipótese de incidência da respectiva obrigação, ainda que isentos ou imunes, em solidariedade ou na condição de substitutos tributários.

\subsection{5 - Contabilizações e pagamento dos documentos fiscais}

Após a plena realização dos itens anteriores, o documento fiscal deve ser remetido ao departamento contábil que providenciará o devido registro da obrigação no sistema contábil da empresa.

Nas empresas contatadas, a ferramenta oficial de contabilidade é o Sistema de Administração Financeira (Siafi), que através da transação >ATUCPR providenciam a contabilização dos documentos fiscais. A transação remete o usuário a 8 telas que deverão ter seus campos preenchidos e ao final após a confirmação na ultima tela há validação pelo sistema dos principais campos que possuem critica sendo que caso haja algum campo com erro devolve mensagem ao usuário para que seja providenciado o respectivo ajuste.

Em tela especifica da transação citada acima, o usuário deverá preencher os dados necessários à correta retenção dos impostos incidentes sobre as compras de bens e serviços. $\mathrm{Na}$ questão relacionada ao imposto municipal, o usuário deverá preencher os dados que servirão para o registro contábil da obrigação, como também para a futura confirmação do recolhimento aos cofres municipais. É uma função de grande importância e responsabilidade por parte do profissional da área, pois um dado digitado incorretamente, um vencimento em data posterior ao estipulado, um percentual aplicado a menor, ou erro na definição do município arrecadador, poderá trazer uma grande dor de cabeça para a organização que fatalmente será punida ao rigor 
da lei. Neste particular podemos perceber mais uma rotina implantada pelas empresas em razão da imputação da responsabilidade tributária por parte das prefeituras municipais.

\subsection{1 - Contabilização da despesa e do reconhecimento das obrigações}

A contabilização do imposto devido ao município deverá ser providenciada no momento do reconhecimento da despesa relacionada à prestação dos serviços e em obediência ao principio da competência, assim temos os seguintes lançamentos:

Debito: Despesas com serviços de terceiros - pessoa física/jurídica

- Prestação de serviços processamento de dados (Valor bruto dos serviços).

Crédito: Passivo Circulante - Fornecedor PD Ltda (Valor líquido do documento fiscal)

Crédito: Passivo Circulante - Impostos Municipais (Valor do ISS).

\subsection{2 - Do pagamento ao fornecedor}

Quando do vencimento da obrigação deverá ser realizado os seguintes registros contábeis:

> Debito: Passivo Circulante - Fornecedor PD Ltda. (valor líquido do documento fiscal).

Crédito: Ativo Circulante - Bancos (Pelo valor líquido do documento fiscal)

\subsection{3 - Do recolhimento do imposto}

$\mathrm{Na}$ data estipulada pela legislação municipal para o recolhimento do imposto, a organização contábil da empresa deverá realizar os seguintes registros contábeis:

Debito: Passivo Circulante - Impostos Municipais (Pelo valor do ISS). 
Crédito: Ativo Circulante - Bancos (Pelo valor líquido do documento fiscal).

\subsection{6 - Controle dos impostos retidos na fonte}

$\mathrm{Na}$ medida em que a empresa possua muitos contratos com terceiros relacionados à prestação de serviços, há que se realizar controle rígido dos valores retidos na fonte, incluindo analises que possam garantir que os valores estejam corretos, e também conciliações diárias e mensais que evitem que haja pagamento aos fornecedores sem o respectivo recolhimento dos impostos relacionados.

Os controles dos impostos retidos, e recolhidos, visam atender a futuras fiscalizações, que geralmente solicitam estes controles para efeito de confirmação dos valores recolhidos, se estes estão de acordo com a legislação fiscal.

\subsection{7 - Sistema de controle de fornecedores (SICAF)}

O Sistema de Cadastramento Unificado de Fornecedores (SICAF), subsistema do Sistema Integrado de Administração de Serviços Gerais (SIASG), foi desenvolvido e implantado visando à modernização e reforma do estado, como meio de torná-lo mais eficiente, e voltado principalmente ao interesse da sociedade. Neste sistema, todos os fornecedores que tiverem interesse em fornecer materiais e serviços para órgãos da administração pública federal direta, suas autarquias e fundações, deverão realizar seu cadastramento e assim poder, em qualquer parte do país, participar de licitações públicas.

Para que o cadastramento seja viabilizado, as empresas devem apresentar:

$>$ Balanço Patrimonial e as demonstrações contábeis, que comprovem boa situação financeira;

$>$ Certidão negativa de falência ou concordata;

> Prova de inscrição no cadastro de contribuintes estadual ou municipal;

> Prova de regularidade para com a Fazenda Estadual e Municipal;

$>$ Certidões do INSS e do FGTS; 
De posse de toda a documentação acima, o órgão cadastrador realizará a avaliação jurídica da legalidade de constituição da empresa, a análise da capacidade econômico-financeira e a análise da regularidade fiscal.

Todas as certidões são válidas por um determinado tempo, devendo ser renovadas e reapresentadas ao órgão cadastrador para efeito de validação no SICAF.

O SICAF foi implantado tendo como base a Instrução Normativa $\mathrm{n}^{\circ} 05$ do antigo Ministério da Administração e Reforma do Estado - MARE (BRASIL, 1995).

\subsection{8 - Lei de Licitações}

Conforme a CF/88 (BRASIL, 1988), todos os órgãos da Administração Pública direta e indireta, em seus processos de compras obedecerão a processo regular de licitação pública. Tal determinação está descrita no inciso XXI, do artigo 37, Capítulo VII - Da Administração Pública, Seção I - Disposições Gerais.

XXI - ressalvados os casos especificados na legislação, as obras, serviços, compras e alienações serão contratados mediante processo de licitação pública que assegure igualdade de condições a todos os concorrentes, com cláusulas que estabeleçam obrigações de pagamento, mantidas as condições efetivas da proposta, nos termos da lei, o qual somente permitirá as exigências de qualificação técnica e econômica indispensáveis à garantia do cumprimento das obrigações;

A Lei $n^{0} 8.666$ (BRASIL, 1993) veio regulamentar o inciso XXI, citado acima, estabelecendo as normas gerais sobre licitações e contratos administrativos pertinentes a obras, serviços, inclusive publicidade, compras, alienações e locações no âmbito dos Poderes da União, dos Estados, do Distrito Federal e dos Municípios.

Pelo parágrafo único do art. $1^{\circ}$, as empresas públicas, as sociedades de economia mista e demais entidades controladas direta ou indiretamente pela União, Estados, Distrito Federal e Municípios, é determinado à subordinação ao regime da citada Lei no 8.666(BRASIL, 1993).

\subsection{9 - Nota Fiscal Eletrônica}

A Nota Fiscal Eletrônica tem se mostrado como o processo que mais modernidade trouxe aos contribuintes, a sociedade e às administrações publicas das três esferas. Pode-se esperar com a implantação de tal processo redução de custos imediatamente percebidos, benefícios para o meio ambiente, melhoria dos controles das empresa e das administrações 
tributárias, e facilidades para quem compra e para quem vende. Alguns benefícios podem ser citados, tais como:

Redução de custos de impressão;

$>$ Redução de custos de aquisição de papel (menos arvores derrubada);

$>$ Redução de custos de envio do documento fiscal (o meio é eletrônico);

$>$ Redução dos custos de armazenagem dos documentos fiscais;

> Simplificação de obrigações acessórias, como dispensa de AIDF;

$>$ Redução do tempo de parada de caminhões em Postos Fiscais de Fronteira;

$>$ Incentivo a uso de relacionamentos eletrônicos com clientes (quem compra poderá se valer dos arquivos das notas fiscais recebidos e atualizar seus processos internos - almoxarifado - contabilidade - custos);

$>$ Redução de consumo de papel;

> Modernização tecnológica dos fiscos e das empresas envolvidas;

$>$ Melhorias nos processos de controle fiscal, possibilitando um melhor intercâmbio e compartilhamento de informações entre os físcos, na medidas em que as informações serão padronizadas;

Aumento na confiabilidade da Nota Fiscal;

$>$ Redução de custos no processo de controle das Notas Fiscais capturadas pela fiscalização de mercadorias em trânsito;

Diminuição da sonegação fiscal;

Suporte aos projetos de escrituração eletrônica contábil e fiscal da Secretaria da Receita Federal do Brasil (SRFB).

Segundo Almeida, diretor de Serviços Compartilhados da Gerdau (2008, p 12), "a empresa emite 180 mil notas fiscais, sendo que $72 \%$ deste volume já eletronicamente, o que reduziu em 4,7 milhões de folhas de papel por ano, baixando consideravelmente os custos de impressão e aquisição de papel. Também reduziu os custos de armazenamento de documentos, eliminação de digitação das notas fiscais na recepção das mercadorias, e ainda redução de erros de escrituração por digitação incorreta". Almeida ressalta ainda que "opera com Nota Fiscal eletrônica em 17 estados, e que a nova tecnologia melhora a relação com os clientes e fornecedores pelo fato de trazer a antecipação das informações, o que permite melhor planejamento, melhor gerenciamento e maior agilidade no processo de entrada de mercadorias." 
Todas os 27 (vinte e sete) estados da Federação já participam do projeto NF-e, e o documento tem validade em todo o território nacional. Ainda segundo Machado (2008, p. 12), “a expectativa é de que, até o final do ano, o volume mensal de notas fiscais entregues no repositório nacional de dados chegue a dez milhões de unidades.

Segundo Cesero, Superintendente de Administração Tributária e Comércio Exterior do Serpro (2008, p. 16), os municípios, a reboque destas novas tecnologias, também poderão utilizar o SPED, para tratamento dos documentos fiscais dos prestadores de serviços, inscritos no cadastro de contribuintes do ISSQN.

\begin{abstract}
Ainda no mesmo modelo da NF-e, está sendo concebido em conjunto com a Associação Brasileira de Secretarias de Finanças das Capitais (Abrasf) o projeto da Nota Fiscal de Serviços Eletrônica (NFS-e), que ampliará as facilidades dos documentos digitais ao conjunto dos prestadores de serviços, possibilitando também um controle tributário mais efetivo por parte dos municípios sobre o Imposto sobre Serviços de Qualquer Natureza (ISSQN).

Além desses, uma série de novos serviços pode ser incorporados ao Sped, o que abre caminho para que o Brasil tenha uma gestão tributária cada vez mais eficiente. $\mathrm{O}$ Sped é fruto de uma construção coletiva, que envolveu vários agentes organizadores, como a Receita Federal do Brasil, o Serpro os Estados, municípios, outros entes e também as empresas. Todos participaram, desde o início, do planejamento e do desenvolvimento da solução. Isso criou um ambiente favorável para que uma série de funções sejam integradas, tanto no que diz respeito aos processos de negócios quanto à parte tecnológica, conclui.
\end{abstract}

\title{
2.20 - Sistema Público de Escrituração Digital - SPED
}

O Sistema Público de Escrituração Digital (SPED) foi instituído pelo Decreto $\mathrm{n}^{\circ} 6.022$ de 22 de janeiro de 2007, (BRASIL, 2007), constituindo-se em mais um avanço na informatização da relação entre o fisco, os contribuinte e a sociedade. Traz em seu bojo a modernização da sistemática atual do cumprimento das obrigações acessórias, sendo que todos os documentos gerados para o SPED são eletrônicos, com validade jurídica para todos os fins, garantida pela utilização da Certificação Digital padrão ICP Brasil, conforme Medida Provisória 2200-2, de 24 de agosto de 2001.

O SPED faz parte do projeto de modernização da administração tributária e aduaneira do Brasil. Promove a atuação integrada dos fiscos federal, estadual e municipal, mediante a padronização das informações fiscais. Os livros contábeis e fiscais, bem como outras obrigações acessórias em papel, serão substituídos por arquivos eletrônicos.

Todos os arquivos do SPED são transmitidos via internet para a secretaria de fazenda (Sefaz) jurisdicionante, responsável por autorizar a emissão do documento e o trânsito da mercadoria. 
O SPED é composto por três grandes subprojetos:

- Escrituração Contábil Digital (ECD);

- Escrituração Fiscal Digital (EFD); e

- Nota Fiscal Eletrônica (NF-e).

Representa uma iniciativa integrada das administrações tributárias nas três esferas governamentais. Mantém parceria com 20 instituições, entre órgãos públicos, conselho de classe, associações e entidades civis, na construção conjunta do projeto.

Firma protocolo de cooperação com 27 empresas do setor privado, participantes do projeto-piloto. Objetivando o desenvolvimento e o disciplinamento dos trabalhos conjuntos.

Possibilita, com parcerias fisco-empresa, planejamento e identificação de soluções antecipadas no cumprimento das obrigações acessórias, em face às exigências a serem requeridas pelas administrações tributárias.

Faz com a efetiva participação dos contribuintes na definição dos meios de atendimento às obrigações tributárias acessórias exigidas pela legislação tributária contribua para aprimorar esses mecanismos e confira a esses instrumentos maior grau de legitimidade social.

Estabelece um novo tipo de relacionamento, baseado na transparência mútua, com reflexos positivos para toda a sociedade.

Espera-se que após implantado integralmente todas as três grandes áreas de atuação do SPED, e com a participação de todas as empresas no processo, haja a liberação do cumprimento das obrigação assessorias, pois o sistema deve receber todas as informações necessárias ao efetivo controle da arrecadação por parte das três esferas de governo. 


\section{3 - Metodologia}

Pretende-se aqui descrever a metodologia e as técnicas de pesquisa a serem adotadas no mapeamento das competências de acordo com as abordagens até aqui descritas.

Constata-se na literatura que a definição metodológica para uma pesquisa empírica tem sido de fundamental importância para as pretensões do pesquisador, que deve informar o que pretende investigar e o porquê de tal pesquisa. Também tem como objetivo apresentar conceitos e exemplos sobre população, amostra e seleção dos sujeitos, objetos da pesquisa, dentre outros aspectos relacionados ao desenho da pesquisa (VERGARA, 2000).

\section{1 - Tipo de pesquisa}

Será feita uma pesquisa quantitativa. Ela será realizada em razão do foco do trabalho, que direciona para interpretação de dados reais, utilizando-se de questionário estruturado com questões claras e objetivas, evitando que o entrevistado utilize em suas respostas subjetivas que dificulte a análise dos resultados, sem a pretensão de explicar ou fazer qualquer tipo de interferência a respeito das questões apontadas pelos entrevistados (VERGARA, 2000), embora o estudo possa contribuir para ampliar o debate sobre o tema.

Visando levantar o perfil de cada empresa participante, também serão solicitados no questionário que seja respondido questões que envolvam os riscos nos processos de análise tributária, bem como sobre a forma como é desenvolvida as rotinas internas de tramitação e acompanhamento dos documentos fiscais dentro da organização.

A pesquisa de campo, conforme ressalta Vergara (2000), serão coletados dados nas instituições onde ocorrem os fenômenos investigados.

Será utilizada a técnica de resposta á questões pontuais, tendo em vista a natureza pessoal e reservada do assunto que será tratado e que, dado objetivo do estudo, pretende-se maximizar a oportunidade de compreender as diferentes percepções dos entrevistados sobre os impactos da substituição tributária.

No que dizem respeito aos procedimentos metodológicos, as pesquisas quantitativas de campo exploram as técnicas de observações e entrevistas devido à propriedade com que as esses instrumentos penetram na complexidade de um problema (RICHARDSON, 1999, p.82). 


\section{2 - Caracterização da organização}

A pesquisa será realizada nos setores contábeis das empresas públicas da esfera federal, usuárias do Sistema Integrado de Administração Financeira (SIAFI), sendo direcionada para os gestores ligados a análise de documentos fiscais, quanto à definição dos tributos incidentes sobre os serviços tomados.

\section{3 - Participantes da Pesquisa e Amostra de Documentos}

Participarão da pesquisa os responsáveis diretos, dos setores contábeis e tributários das empresas estatais federais, sendo previamente eleitos os chefes de departamento e de divisões, lotados em Brasília, Distrito Federal, cuja escolha será feita por acessibilidade, já que os elementos de cada categoria serão selecionados pelo grau de acessibilidade.

A pesquisa também está sendo encaminhada a uma empresa sediada na Cidade do Rio de Janeiro.

\subsection{1 - Seleção dos Participantes}

Os sujeitos da pesquisa serão os integrantes das empresas estatais federais, em cargos de comissão, escolhidos com base na acessibilidade, conforme mencionado no item anterior.

\section{4 - Instrumento}

Existem vários tipos de entrevistas. Neste estudo serão utilizados dois tipos, a entrevista estruturada e a não estruturada. A entrevista estruturada é construída com perguntas e respostas pré-formuladas, usualmente chamada de questionário. Este questionário será baseado nas legislações vigentes que possuem as mesmas obrigações legais de substituir o contribuinte na apuração, retenção e recolhimento do imposto sobre serviços de qualquer natureza (ISSQN), que tem o intuito de gerar informações aos administradores públicos e à sociedade em geral sobre os procedimentos adotadas para realização do processo da substituição tributária. A entrevista não estruturada visa obter do entrevistado o que ele considera os aspectos mais relevantes de determinado problema, ou seja, as descrições de uma situação em estudo; neste caso, será utilizado uma conversação orientada (RICHARDSON, 1999, p.208). Nesta etapa, será verificado a situação dos dados das empresas estatais quanto a quantidade de empregados 
envolvidos nos processos tributários, como a quantidade de analistas, técnicos e auxiliares que executam esta atividade, bem como os dados correlacionados, tais como: a remuneração de cada empregados, a quantidade de documentos fiscais tratados, os recursos materiais e tecnológicos utilizados, os sistemas, os municípios onde ocorrem os fatos geradores dos tributos e, demais dados relacionados com a substituição tributária.

\section{5 - Procedimentos de coleta dos dados}

A realização da pesquisa nas empresas estatais será precedida de prévia e expressa autorização das organizações

Para que os entrevistados se sintam mais à vontade durante os contatos, além de esclarecer, previamente, que a entrevista objetiva coletar dados para uma pesquisa acadêmica, será garantido aos indivíduos o sigilo total e absoluto sobre o conteúdo das informações coletadas, além da omissão de nomes e unidade de lotação. Será feito, também, um compromisso quanto ao conhecimento do resultado do trabalho, posteriormente à conclusão.

\section{6 - Análise dos dados}

Será feita análise de conteúdo das informações obtidas, que, posteriormente, serão categorizadas nas etapas de redução dos impactos causados pela substituição tributária nas empresas estatais para uma redução dos custos, desenvolvimento de novas ferramentas e, principalmente para avaliar o grau de desgaste dos empregados envolvidos nesta atividade. A análise dos dados, também, será de grande importância para demonstrar a preocupação dos empregados envolvidos nesta etapa com relação ao rigor das legislações vigentes na execução atividade, substituição tributária, à alta gestão das empresas estatais. 


\section{4 - Análise dos Resultados}

O questionário foi enviado por e mail a cinco empresas estatais, com um prazo razoável para resposta. Posteriormente foi enviado cobrança através da internet, sendo que somente a Financiadora de Estudos e Projetos - FINEP se pronunciou enviando o questionário devidamente preenchido.

O questionário também foi aplicado no Departamento Tributário do Serviço Federal de Processamento de Dados (SERPRO), empresa com capilaridade em todos os estados brasileiros, demonstrando assim uma importante fonte de pesquisas para os resultados esperados.

\section{1 - Questionário Básico}

Visando facilitar e permitir conhecer os processos e as dificuldades enfrentadas pelas áreas de análise tributária e de contabilidade, foi elaborado um questionário que também visava conhecer os gastos adicionais que as atividades relacionadas ao trato de documentos fiscais trouxeram às empresas na medida em que estas foram consideradas substitutas tributárias pelas administrações municipais.

Na empresa "A", 9 (nove) profissionais tomam conta de todos os documentos fiscais enquanto que na empresa "B", se utiliza de 3 (treis) profissionais.

No quadro abaixo 1 (um), é identificado a quantidade de empregados que lidam diretamente com as atividades de conferência dos documentos fiscais na Finep e no Serpro, bem como a remuneração mensal total em cada empresa pesquisada.

Quadro 1 - Remuneração média mensal dos empregados envolvidos

\begin{tabular}{|c|c|c|r|r|}
\hline \multicolumn{2}{|c|}{ Quantidade de Empregados } & Cargo & \multicolumn{2}{c|}{ Remuneração Total Mensal } \\
\hline \hline Empresa "A" & Empresa "B" & & Empresa "A" & Empresa "B" \\
\hline \hline $\mathbf{3}$ & - & Auxiliar & $\mathbf{9 . 7 0 6 , 3 5}$ & - \\
\hline 4 & $\mathbf{1}$ & Técnico & $\mathbf{1 6 . 0 0 6 , 8 2}$ & $\mathbf{3 . 0 0 0 , 0 0}$ \\
\hline $\mathbf{2}$ & $\mathbf{2}$ & Analista & $\mathbf{1 2 . 5 9 1 , 5 6}$ & $\mathbf{1 0 . 0 0 0 , 0 0}$ \\
\hline $\mathbf{9}$ & $\mathbf{3}$ & Total & $\mathbf{3 8 . 3 0 4 , 7 3}$ & $\mathbf{1 3 . 0 0 0 , 0 0}$ \\
\hline
\end{tabular}

No quadro 2 (dois) abaixo, há a informação dos encargos trabalhistas aplicados sobre a remuneração mensal e total, aplicados sobre a remuneração dos trabalhadores que lidam com a documentação fiscal nas empresas Finep e Serpro. 
Quadro 2 - Encargos Trabalhistas Aplicado sobre a Remuneração Mensal

\begin{tabular}{|l|c|r|r|}
\hline \multicolumn{1}{|c|}{ Rubrica } & Percentual & Empresa “A” & Empresa "B” \\
\hline \hline Previdência Social Parte Empregador & $20,00 \%$ & $7.660,95$ & $2.600,00$ \\
\hline Entidades de Assist. ao Trabalhador & $4,30 \%$ & $1.647,10$ & 559,00 \\
\hline Salário Educação & $2,50 \%$ & 957,26 & 325,00 \\
\hline FGTS & $8,00 \%$ & $3.064,38$ & $1.040,00$ \\
\hline $13^{\circ}$ Salário & $8,33 \%$ & $3.190,78$ & $1.082,90$ \\
\hline Férias & $8,33 \%$ & $3.190,78$ & $1.082,90$ \\
\hline \multicolumn{1}{|c|}{ Total de Encargos mensais } & $\mathbf{5 1 , 4 6 \%}$ & $\mathbf{1 9 . 7 1 1 , 6 1}$ & $\mathbf{6 . 6 8 9 , 8 0}$ \\
\hline
\end{tabular}

Não está computado como custos, os gastos relacionados a alimentação, saúde, qüinqüênios, transporte, etc.

$\mathrm{Na}$ figura 1 (um) a seguir, há a representação gráfica dos gastos mensais com remuneração, seus encargos trabalhistas e o total respectivo acumulado por empresa.

Figura 1 - Gastos Mensais com Pessoal

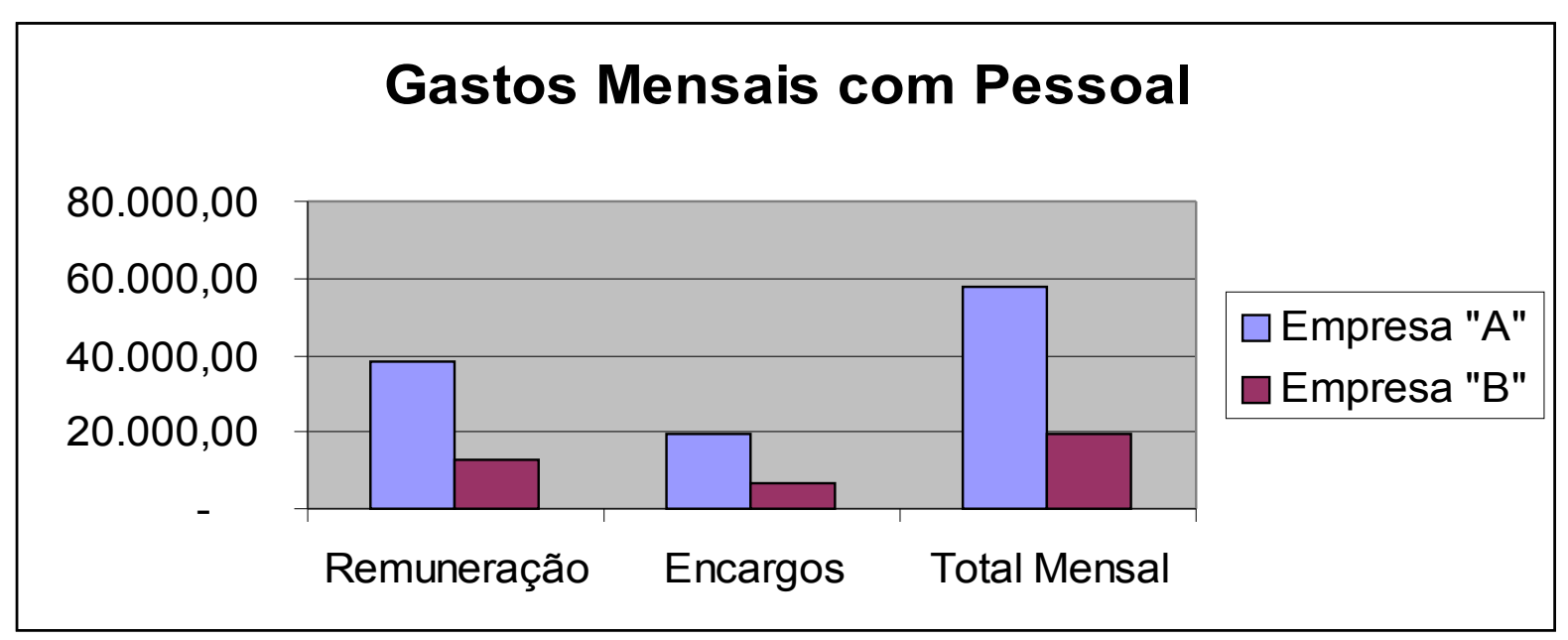

O quadro 3 (três), demonstra os totais gastos por mês e ano, pelas empresas pesquisadas. Nota-se que os gastos são consideráveis, sendo estes necessários ao atendimento das obrigações imputadas pelas obrigações acessórias por parte dos municípios.

Quadro 3 - Total de Gastos por ano

\begin{tabular}{|c|c|r|}
\hline Empresa & Remuneração + Encargos & Total Anual \\
\hline "A" & $\mathbf{5 8 . 0 1 6 , 3 4}$ & $\mathbf{6 9 6 . 1 9 6 , 1 3}$ \\
\hline "B" & $\mathbf{1 9 . 6 8 9 , 8 0}$ & $\mathbf{2 3 6 . 2 7 7 , 6 0}$ \\
\hline
\end{tabular}

Já na figura 2(dois), há a representação gráfica dos totais gastos por ano pelas empresas Finep e Serpro. 
Figura 2 - Gastos Anuais com Pessoal

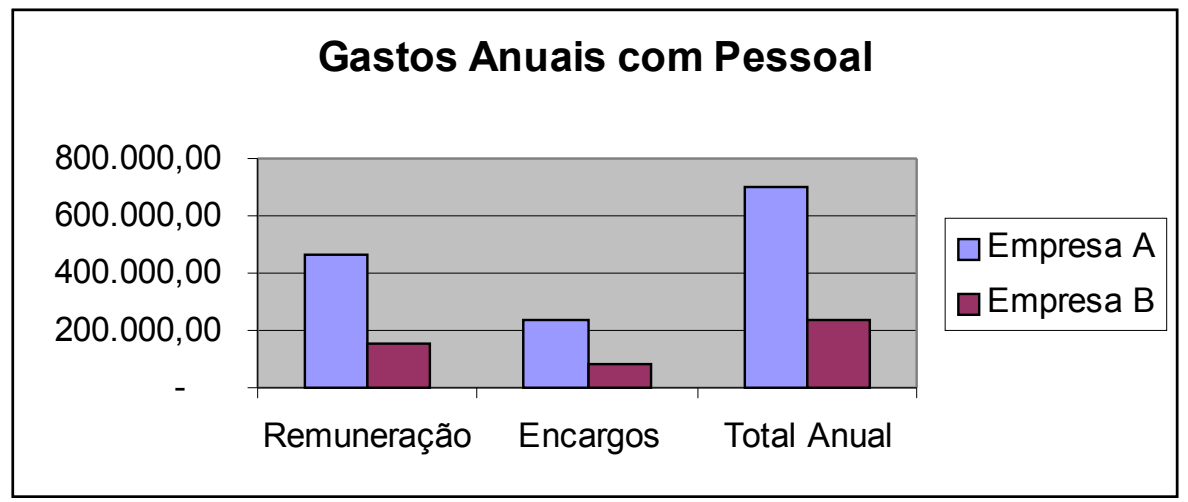

O quadro 4 (quatro) demonstra a quantidade de documentos tratados por mês e por ano nas empresas Finep e Serpro.

Quadro 4 - Quantidade média de Documentos Fiscais Tratados

\begin{tabular}{|c|c|c|}
\hline EMPRESA & DOCUMENTOS MÊS & TOTAL ANO \\
\hline A & 1.060 & 12.720 \\
\hline B & 400 & 4.800 \\
\hline
\end{tabular}

Abaixo, através da figura 3 (três), há a representação gráfica da média de documentos fiscais tratados pelas empresas Finep e Serpro, por mês e por ano.

Figura 3 - Quantidade média de documentos

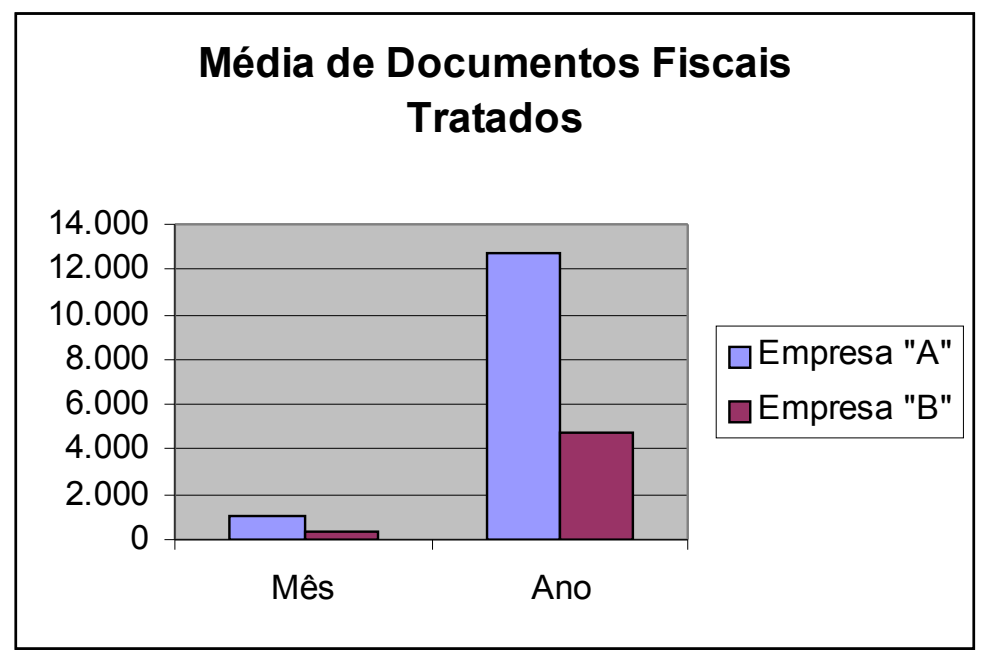




\section{2 - Recursos tecnológicos utilizados}

A Finep não se utiliza de nenhum recurso tecnológico para auxiliar as atividades de conferência e preparo dos documentos fiscais para registro no Siafi.

No Serpro, a área de análise tributária do Serpro utiliza atualmente uma planilha desenvolvida através do aplicativo Excel que facilita em muito o controle e as conferências, principalmente dos valores dos documentos fiscais relacionados às compras de bens e serviços.

Ao abrir o documento no aplicativo Excel, a planilha, em forma de formulário, é preenchida, sendo que os campos de valores servem de base para a conferência do documento fiscal. A planilha após o preenchimento é impressa e acompanha o documento fiscal, servindo de base para o lançamento no Sistema Integrado de Administração Financeira - Siafi, que através do Módulo: Atualiza CPR - Contas a Pagar e a Receber, realiza a contabilização das despesas e reconhece todos os impostos incidentes sobre as compras.

Está sendo desenvolvido no Serpro, um sistema integrado que possibilitará o desencadeamento de diversas rotinas que auxiliará tanto os gestores de contratos como os registros contábeis de todas as despesas da empresa realizadas através de licitação.

Este sistema denominado de Histórico de Aquisições e Contratos (HISAQ) ao ser acionado trará algumas telas já preenchidas, pois neste, todos os contratos após a publicação serão registrados.

Está também previsto para este sistema, a apresentação de extratos dos contratos e envios de arquivos com os registros das liquidações das despesas para que a área de análise tributária possa então, em campos específicos, registrar os impostos incidentes sobre os documentos fiscais. Posteriormente este arquivo, ainda dentro do Hisac, será enviado à área contábil para que então, seja validado todas as informações e confirmação do registro no Siafi, tudo isto de forma automatizada.

Como este sistema visa auxiliar todas as fases da despesa, e seus desdobramentos, no projeto que está sendo desenvolvido, os analistas já foram orientados a incluir campos que possam absorver os dados necessários aos registros e pagamento de todos impostos incluídos nos documentos fiscais.

Aqui cabe salientar mais uma vez os custos advindos com a imputação das responsabilidades por substituição tributária por parte dos municípios, que não avaliam o quanto as empresas gastam com o cumprimento destas obrigações. É claro que nada sai de "graça", estes custos com certeza são embutidos nos preços dos serviços praticados, repercutindo por conseqüência nos impostos calculados sobre estes preços. 
Neste novo sistema, os responsáveis pelas compras de bens e serviços, incluirão além dos dados específicos do processo de compra, as fundamentações legais, as informações da demanda de acordo com o tipo de contratação, e o valor da contratação, sendo que após as assinaturas e registros dos contratos, a inclusão destes em módulo desenvolvido para recepção dos registros.

Conforme figura 4 (quatro) abaixo, a planilha que é inserida no aplicativo excel, além de auxiliar os profissionais da área tributária e contábil nas questões que envolvem cálculos e informações para a correta aplicação da contabilidade, serve também como para registro de datas de protocolo, assinaturas relativas às autorizações de pagamentos que é dada por parte dos responsáveis pelas emissões das Ordens Bancárias, e inclusão de dados relativos aos documentos que foram gerados no Siafi, tais como os números das Notas de Sistema (NS), das Notas de Pagamento (NP) e das Ordens Bancárias emitidas.

Figura 4 - Modelo de Planilha utilizada

CARIMBO DA EBC - EMPRESA BRASIL DE COMUNICAÇÃO

\begin{tabular}{|c|c|c|c|}
\hline \multicolumn{3}{|c|}{$\begin{array}{l}\text { A NEXO DOC - F IS C AL : } \\
\text { VENCIMENTO: }\end{array}$} & DA TA EM IS S ÃO NF \\
\hline \multicolumn{3}{|c|}{ CGC/CPF/UG GESTÃO } & \multirow[t]{2}{*}{ DATA ATESTENF } \\
\hline $115406-$ & 20415 & & \\
\hline \multicolumn{3}{|c|}{$\begin{array}{l}\text { BANCO/AG./ C/C } \\
\text { GRU }\end{array}$} & CONTRATO-RG \\
\hline $\begin{array}{l}\text { Dс.нав В } \\
\text { NP }\end{array}$ & $\begin{array}{l}\text { S rrua ação } \\
\text { P01 }\end{array}$ & IN S C R $\cdot 2$ & $\begin{array}{r}\text { C ENTROC USTO } \\
3947\end{array}$ \\
\hline SUB-TTEM & CLASSF. 2 & $\mathbf{N E}$ & VALOR \\
\hline 3947 & & 12 & \\
\hline & & & \\
\hline & & & \\
\hline & & & \\
\hline & & & \\
\hline $\mathbf{N}^{\circ} \mathrm{NS}$ & DATA & No NP & $N^{\circ}$ OB \\
\hline AUTOR ZOO PAGT & & $\begin{array}{l}\text { ASSINATURA } \\
\text { FU LANO DE TAL } \\
\text { GEGEG/GEGED /S }\end{array}$ & SUPTE \\
\hline
\end{tabular}
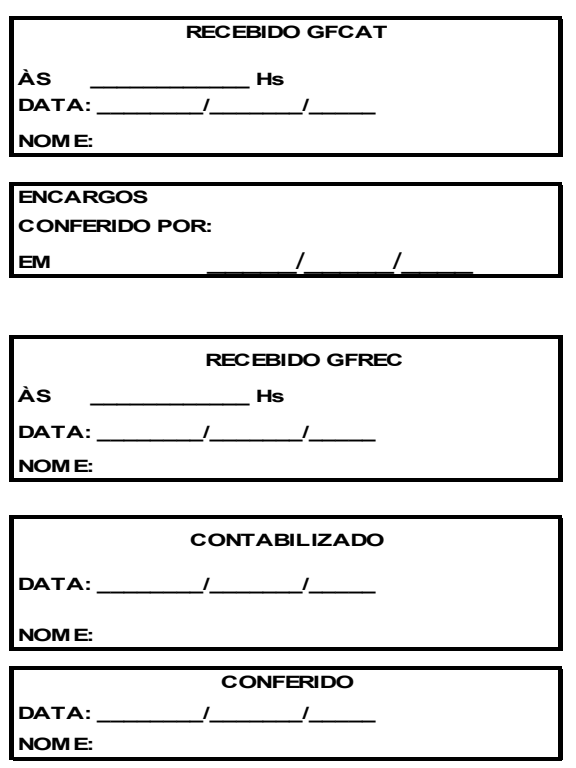

CNPJ: TRIBUTO FEDERAL: 09.168.704/0001-42 - ug(115406/ 20415)

\begin{tabular}{|c|c|c|c|c|c|c|c|}
\hline DADOS & $\%$ & $\begin{array}{c}\text { CODIGO } \\
\text { RECETA }\end{array}$ & VALOR & $\begin{array}{c}\text { BASE } \\
\text { CALCULO }\end{array}$ & VENCTO. & $\begin{array}{c}\text { PERIODO } \\
\text { APURAÇÃO }\end{array}$ & $\begin{array}{c}\text { COD IG ISS USO SRI } \\
189\end{array}$ \\
\hline \multicolumn{2}{|c|}{ VALOR BRUTO } & & & & & & \\
\hline
\end{tabular}


Nas figuras que se seguem de $\mathrm{n}^{\mathrm{o}} \mathrm{s} 5 \mathrm{a}$ 11, os profissionais da área contábil providenciam, conforme determinação de cada campo, o registro dos documentos fiscais no Siafi.

Figura 5 - Tela de registro das obrigações no SIAFI - Dados Básicos

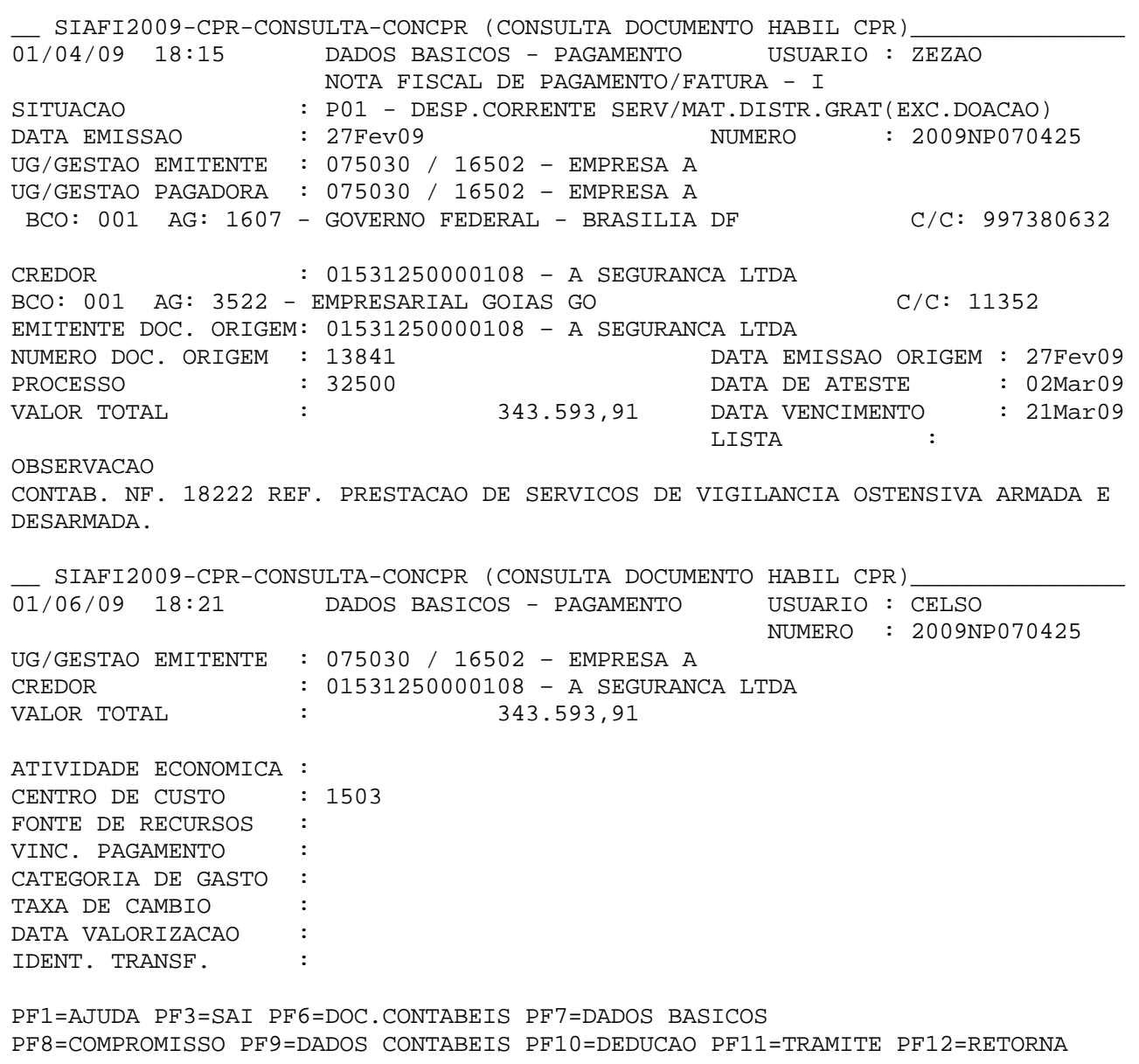

A figura acima demonstra como os campos principais do fornecedor são cadastrados. É através dela que quando do pagamento o sistema Siafi elaborará automaticamente a Ordem Bancária que transferirá os recursos financeiros para a conta do fornecedor.

Figura 6 - Tela de registro das obrigações no SIAFI - Dados Contábeis

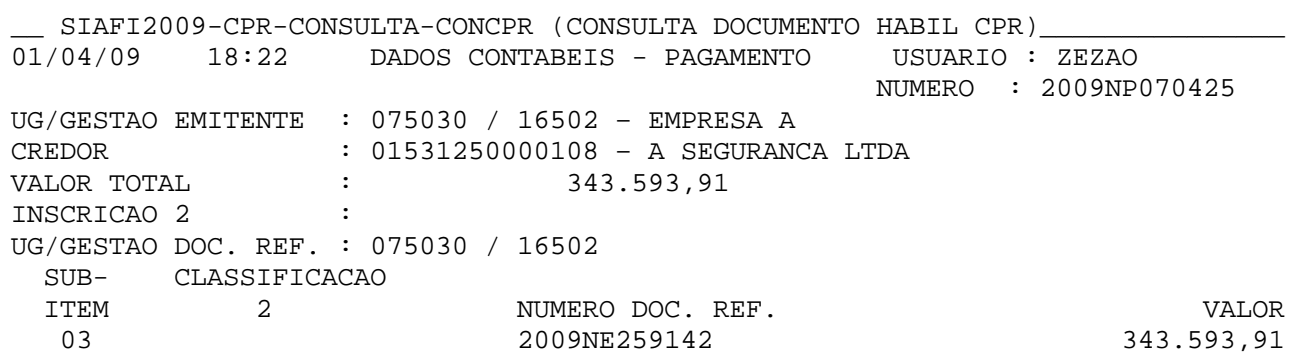


A figura 6 (seis) acima, indica o $\mathrm{n}^{\mathrm{o}}$ do empenho que foi emitido para realizar a compra, e o subitem contábil da despesa que será liquidada.

Figura 7 - Tela de registro das obrigações no SIAFI - Deduções e Encargos

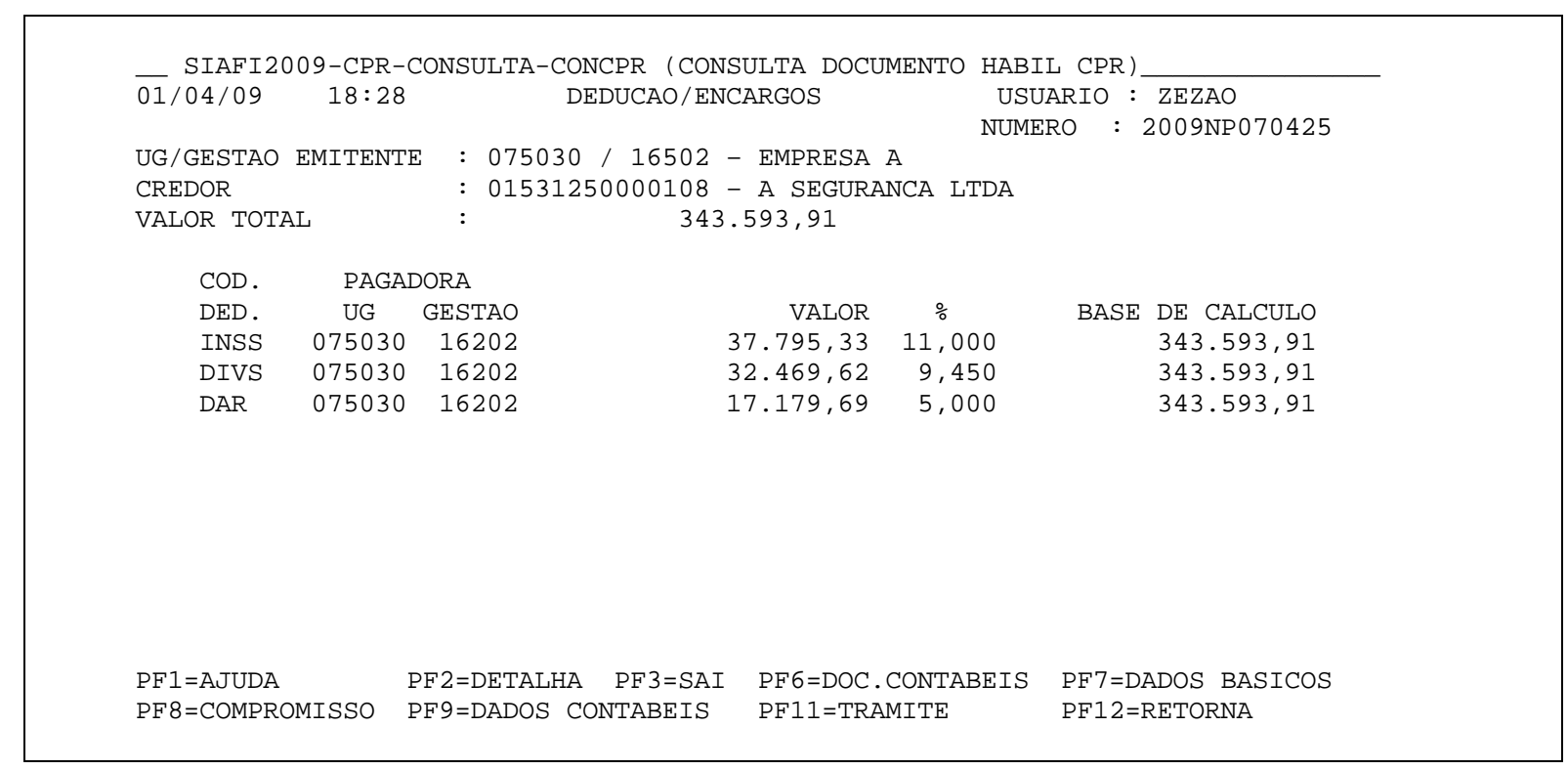

As informações contidas na figura 7 (sete), demonstram quais os impostos serão deduzidos do documento fiscal, sendo que nas próximas figuras serão informados como estes recursos serão repassados aos respectivos agentes arrecadadores.

Figura 8 - Tela de registro das obrigações no SIAFI - Dedução - GPS

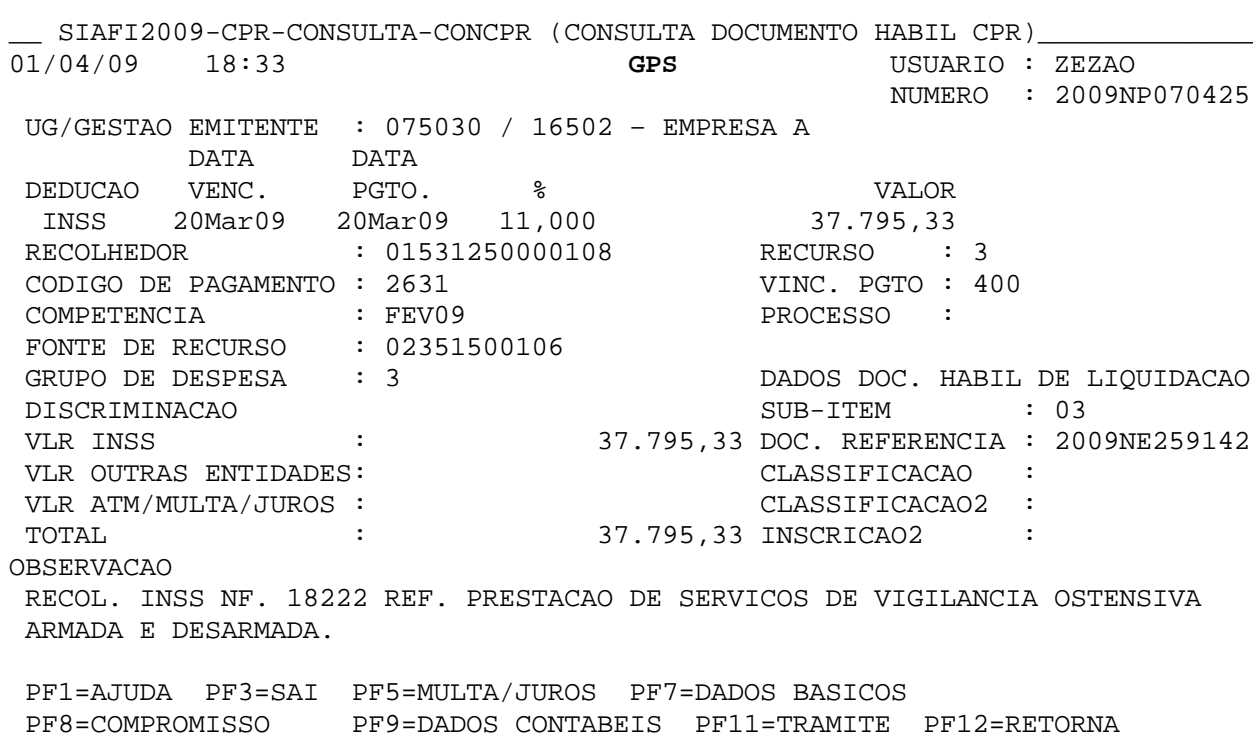

Na figura 8 (oito) há o registro dos campos destinados ao recolhimento do INSS, que quando da confirmação, na data do pagamento, será transformado em Guia de recolhimento da Previdência Social - GPS. 
Figura 9 - Tela de registro das obrigações no SIAFI - Dedução - Impostos Federais

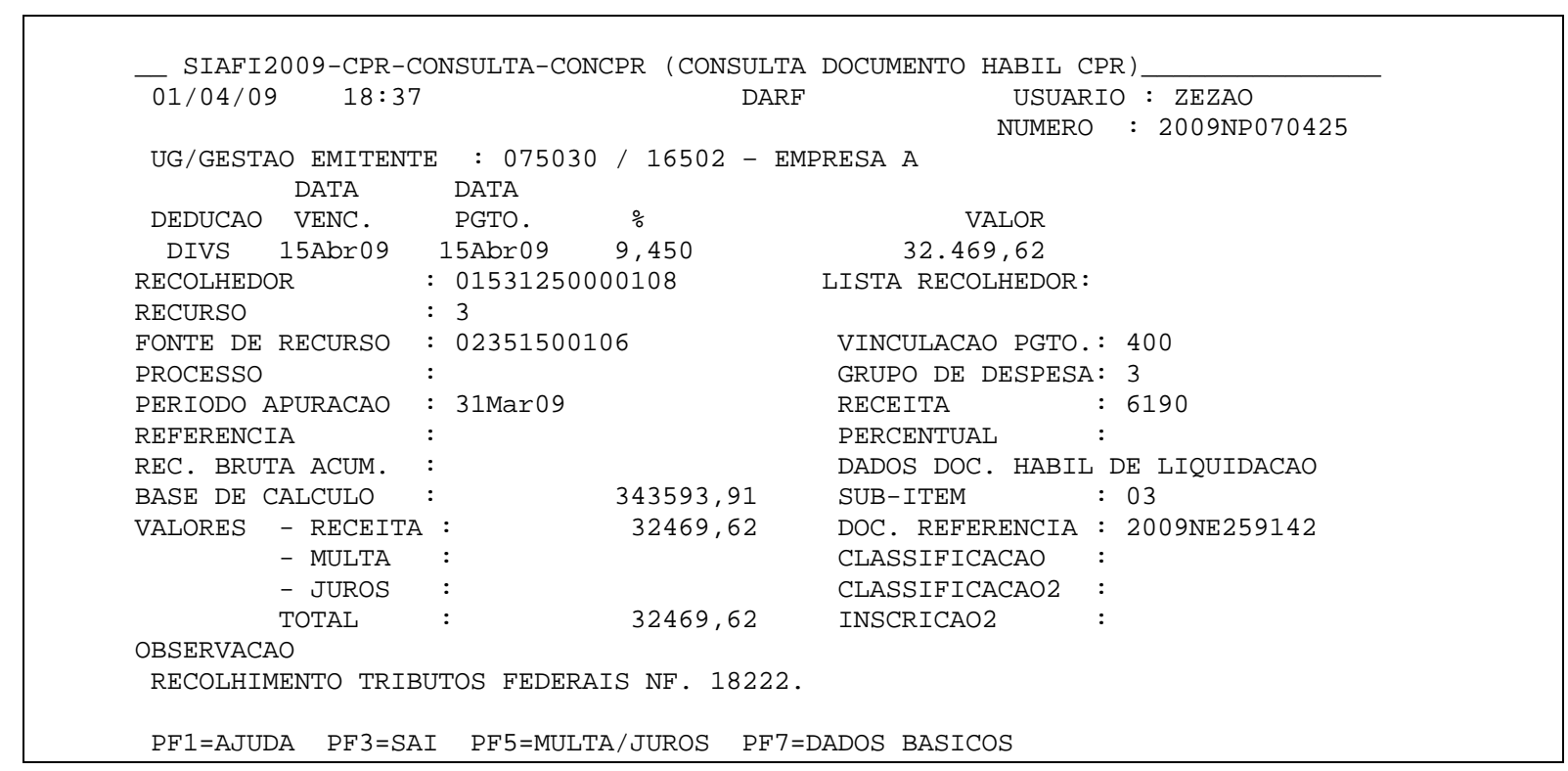

Os dados do Documento de Arrecadação Federal - DARF, estão representados na figura 9 (nove) acima.

Figura 10 - Tela de registro das obrigações no SIAFI - Dedução ISSQN

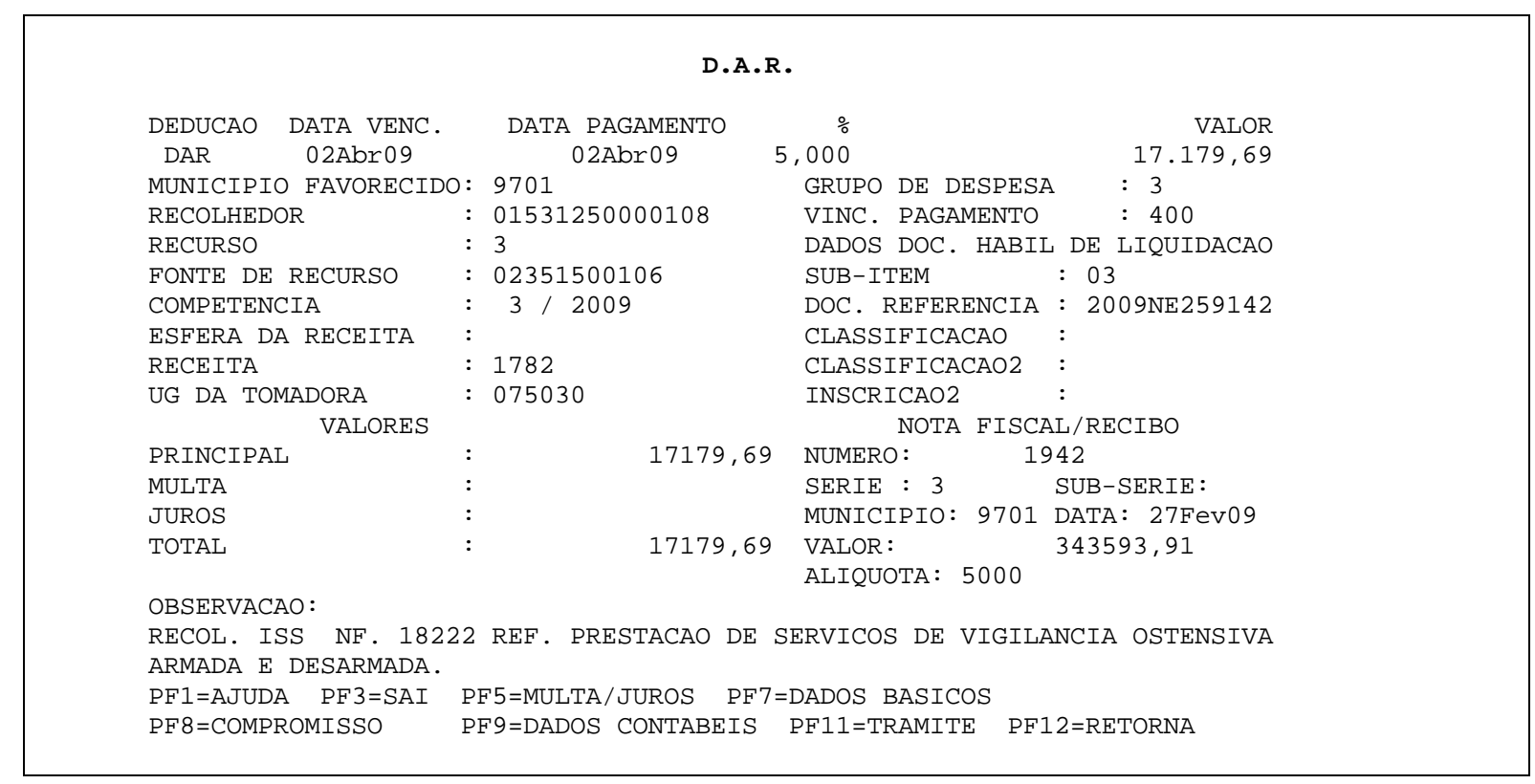

O Imposto sobre Serviços de Qualquer Natureza - ISS será recolhido no prazo previsto, sendo que para tanto, o profissional responsável pelo cadastramento deverá preencher os campos da tela Dedução - DAR, conforme figura 10 (dez) acima.

Após todos os registros realizados no módulo Atucpr do Siafi, o sistema liberará um $\mathrm{n}^{\mathrm{o}}$ de documento, confirmando que os dados estão corretos, e que a Nota Fiscal está devidamente confirmada na contabilidade da empresa. A figura 11 (onze) abaixo, apresenta esta confirmação. 
Figura 11- Tela de registro das obrigações no SIAFI - Confirmação do Registro

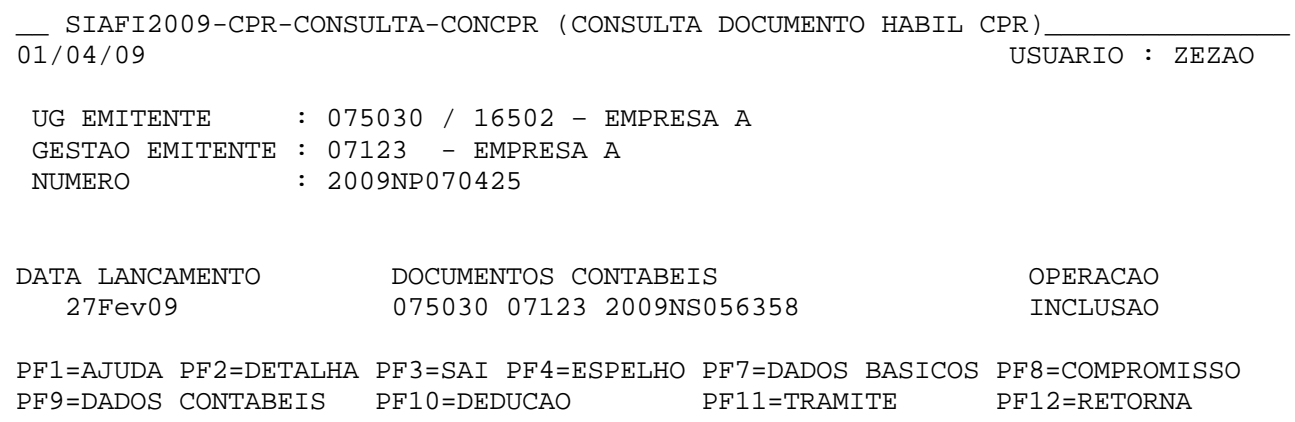

Nos campos das telas acima, o usuário deve realizar com precisão os registros dos dados que futuramente quando do vencimento, será validado através da confirmação da respectiva transferência dos recursos financeiros aos cofres do município, da previdência social e do tesouro nacional.

Os principais campos estão relacionados a:

\section{A - Vencimento da obrigação:}

Neste campo o responsável pelo registro deve consultar a legislação municipal visando conhecer o real vencimento do ISS. O quadro inserido no item 4.8 abaixo indica quais os vencimentos são aceitos pelas diversas legislações municipais.

\section{B - Código do Município:}

Através de tabela constante no Siafi, e em razão do documento fiscal que se esta cadastrando, o usuário deverá registrar o código do município que receberá a retenção do ISS.

\section{C - Código do Recolhedor:}

Neste campo o usuário irá informar o CNPJ do prestador de serviço que está sofrendo a retenção na fonte.

\section{D - Percentual:}

Em procedimento anterior, já se definiu o percentual do imposto deverá ser retido, e neste campo há a indicação de tal percentual.

Ao se preencher todos os campos o usuário deverá ter uma atenção especial para os requisitos, pois uma informação incorreta, poderá gerar recolhimento também incorreto, deixando a empresa vulnerável perante a fiscalização dos municípios. 
Quadro 5 - Relação de Municípios.

O quadro abaixo relaciona todos os municípios onde o Serpro é considerado substituto tributário, e como devem ser elaborados os documentos de arrecadação no módulo Contas a Pagar e a Receber do SIAFI (CPR).

\begin{tabular}{|c|c|c|c|c|c|c|c|}
\hline Município & CNPJ & BANCO & AGÊNCIA & C/CORRENTE & $\begin{array}{l}\text { FATO } \\
\text { GERADOR }\end{array}$ & \begin{tabular}{|l|} 
TP DEDUÇÃO \\
\end{tabular} & VCTO \\
\hline BRASÍLIA & \begin{tabular}{|l} 
CNPJ FORNEC. \\
\end{tabular} & CNPJ & - & - & \begin{tabular}{|l|} 
PGTO NF \\
\end{tabular} & DAR & 05 \\
\hline GOIANIA & CNPJ FORNEC. & CNPJ & - & - & PGTO NF & DAR & 10 \\
\hline CUIABÁ & CNPJ FORNEC. & CNPJ & - & & \begin{tabular}{|l|} 
PGTO NF \\
\end{tabular} & DAR & 15 \\
\hline CAMPO GDE & \begin{tabular}{|l} 
CNPJ FORNEC. \\
N
\end{tabular} & CNPJ & - & - & \begin{tabular}{|l|} 
EMISSÃO NF \\
\end{tabular} & DAR & 15 \\
\hline PALMAS & CNPJ FORNEC. & CNPJ & - & & \begin{tabular}{|l} 
PGTO NF \\
\end{tabular} & DAR & 15 \\
\hline BELÉM & \begin{tabular}{|l} 
CNPJ FORNEC. \\
\end{tabular} & CNPJ & - & & \begin{tabular}{|l} 
PGTO NF \\
\end{tabular} & DAR & 10 \\
\hline MANAUS & CNPJ FORNEC. & CNPJ & - & & DECENDIAL & DAR & $\begin{array}{c}2030 \\
10 \\
\end{array}$ \\
\hline RIO BRANCO & \begin{tabular}{|l|} 
CNPJ SERPRO \\
\end{tabular} & 001 & - & & \begin{tabular}{|l|} 
EMISSÃO NF \\
\end{tabular} & ISS & 10 \\
\hline MACAPÁ & \begin{tabular}{|l|} 
CNPJ SERPRO \\
\end{tabular} & 001 & - & & \begin{tabular}{|l|} 
EMISSÃO NF \\
\end{tabular} & ISS & 10 \\
\hline BOA VISTA & CNPJ FORNEC & CNPJ & - & & \begin{tabular}{|l|} 
PAGTO NF \\
\end{tabular} & DAR & 5 \\
\hline PORTO VELHO & $\begin{array}{l}\text { CNPJ BB } \\
\end{array}$ & 001 & 1607 & & \begin{tabular}{|l|} 
EMISSÃO NF \\
\end{tabular} & ISS & 5 \\
\hline FORTALEZA & \begin{tabular}{|l|} 
CNPJ FORNEC. \\
\end{tabular} & CNPJ & - & & \begin{tabular}{|l|} 
EMISSÃO NF \\
\end{tabular} & DAR & 10 \\
\hline SÃO LUIZ - MA & CNPJ FORNEC. & CNPJ & - & & \begin{tabular}{|l|} 
EMISSÃO NF \\
\end{tabular} & DAR & 10 \\
\hline TERESINA & CNPJ FORNEC. & CNPJ & - & & PAGTO NF & DAR & 10 \\
\hline RECIFE & CNPJ FORNEC. & CNPJ & - & & \begin{tabular}{|l|} 
EMISSÃO NF \\
\end{tabular} & DAR & 10 \\
\hline NATAL & \begin{tabular}{|l|} 
CNPJ FORNEC. \\
\end{tabular} & CNPJ & - & & \begin{tabular}{|l} 
EMISSÃO NF \\
\end{tabular} & DAR & 10 \\
\hline MACEIÓ & CNPJ FORNEC. & CNPJ & - & & EMISSÃO NF & DAR & 10 \\
\hline JOÃO PESSOA & \begin{tabular}{|l|} 
CNPJ FORNEC. \\
\end{tabular} & CNPJ & - & & \begin{tabular}{|l|} 
EMISSÃO NF \\
\end{tabular} & DAR & 10 \\
\hline SALVADOR & CNPJ FORNEC. & CNPJ & - & & PAGTO NF & DAR & 5 \\
\hline ARACAJU & \begin{tabular}{|l|} 
CNPJ BB \\
\end{tabular} & 001 & 1607 & & \begin{tabular}{|l} 
EMISSÃO NF \\
\end{tabular} & ISS & 10 \\
\hline $\begin{array}{l}\text { BELO } \\
\text { HORIZONTE }\end{array}$ & CNPJ FORNEC. & CNPJ & - & & PAGTO NF & DAR & 5 \\
\hline RIO DE JANEIRO & \begin{tabular}{|l|} 
CNPJ BB \\
\end{tabular} & 001 & 1607 & & PAGTO NF & ISS & 5 \\
\hline VITORIA & $\begin{array}{l}\text { CNPJ BB } \\
\end{array}$ & 001 & 1607 & & PAGTO NF & ISS & 10 \\
\hline SÃO PAULO & \begin{tabular}{|l} 
CNPJ FORNEC. \\
\end{tabular} & CNPJ & & & PAGTO NF & DAR & 10 \\
\hline SANTOS & CNPJ BB & 001 & 1607 & & \begin{tabular}{|l} 
EMISSÃO NF \\
\end{tabular} & ISS & 10 \\
\hline RIBEIRÃO PRETO & $\begin{array}{l}\text { CNPJ FORNEC. } \\
\end{array}$ & CNPJ & & & \begin{tabular}{|l|} 
EMISSÃO NF \\
\end{tabular} & DAR & 15 \\
\hline S. J. RIO PRETO & $\begin{array}{l}\text { CNPJ BB } \\
\end{array}$ & 001 & 1607 & & EMISSÃO NF & ISS & 15 \\
\hline BAURU & CNPJ BB & 001 & 1607 & & \begin{tabular}{|l|} 
EMISSÃO NF \\
\end{tabular} & ISS & 15 \\
\hline $\begin{array}{l}\text { PRESIDENTE } \\
\text { PRUDENTE }\end{array}$ & CNPJ BB & 001 & 1607 & & EMISSÃO NF & ISS & 25 \\
\hline CAMPINAS & CNPJ FORNEC. & CNPJ & CNPJ & & EMISSÃO NF & DAR & 10 \\
\hline TAUBATÉ & $\begin{array}{l}\text { CNPJ BB } \\
\end{array}$ & 001 & 0076 & & \begin{tabular}{|l|} 
PAGTO NF \\
\end{tabular} & ISS & 10 \\
\hline CURITIBA & CNPJ FORNEC. & CNPJ & - & & EMISSÃO NF & DAR & 10 \\
\hline FLORIANÓPOLIS & \begin{tabular}{|l} 
CNPJ BB \\
\end{tabular} & 001 & 1607 & & PAGTO NF & ISS & 15 \\
\hline PORTO ALEGRE & CNPJ FORNEC. & CNPJ & - & & PAGTO NF & DAR & 10 \\
\hline
\end{tabular}

A Finep só é considerada substituta tributária perante ao Município do Rio de Janeiro.

\section{3 - Municípios que já emitem as Notas Fiscais eletrônicas}

Conforme decisão tomada no III Encontro Nacional de Administradores Tributários (Enat), encerrado em 10 de Novembro de 2006, as secretarias de finanças dos municípios vão adotar a nota fiscal eletrônica, a exemplo das utilizadas pelos Estados.

A utilização das Nota Fiscais Eletrônicas (NFS-e) permitirá a curto prazo, aumento de competitividade pela racionalização das obrigações acessórias, em especial a dispensa da emissão e guarda de documentos em papel, com isso o trabalho das administrações tributárias 
deve ser facilitado, com a padronização das informações, racionalização de custos e maior eficácia da fiscalização.

Apesar da decisão tomada em Novembro de 2006, no III Enat, até hoje os municípios não colocaram em prática a NFS-e, com exceção do Município de São Paulo.

O Município de São Paulo, já tem legislação que permite a emissão de Notas Fiscais por meio eletrônico, já estando plenamente sendo utilizada pelo Serpro, nas suas prestações de serviços.

A Nota Fiscal eletrônica, instituída pela Lei 14.097 de 08 de dezembro de 2005, pelo Município de São Paulo, é um documento emitido eletronicamente através de sistema disponibilizado pela prefeitura, com o objetivo de registrar as operações relacionadas à prestações de serviços.

Assim como nas Notas Fiscais eletrônicas emitidas para a prestação de serviços, o Serpro, também vem recebendo de seus fornecedores domiciliados no Município de São Paulo, as Notas Fiscais como tomador de serviços.

Está sendo estudado, dentro do Serpro, a possibilidade de ao receber os arquivos digitais contendo as Notas Fiscais Eletrônicas emitidas pelos fornecedores da empresa, enviar os dados constantes do documento fiscal para atualização dos sistemas que tratam tanto do controle das despesas, como dos sistemas contábeis. Com certeza está possibilidade trará ganhos de produtividade e de segurança da informação, pois a mesma já se encontra validada pelos órgãos de controle do município.

\section{4 - Documento de Arrecadação Municipal - DAR}

Trata-se de um instrumento utilizado pelas prefeituras para realizar a arrecadação de tributos municipais. No caso das empresas da União, este documento é eletrônico e é emitido por transação especifica do Siafi, no módulo de Contas a Receber e a Pagar (CPR), já comentado em itens acima.

O quadro abaixo demonstra qual a quantidade média destes documentos emitidos, por mês e por ano, no Serpro e na Finep

Quadro 6 - Quantidade média anual de Documento de Arrecadação - DAR

\begin{tabular}{|c|c|c|c|}
\hline \multicolumn{2}{|c|}{ SERPRO (A) } & \multicolumn{2}{c|}{ FINEP (B) } \\
\hline \hline MÊS & ANO & MÊS & ANO \\
\hline 430 & 5.160 & 150 & 1.800 \\
\hline
\end{tabular}


Figura 12 - Médias de Documentos de Arrecadação - DAR

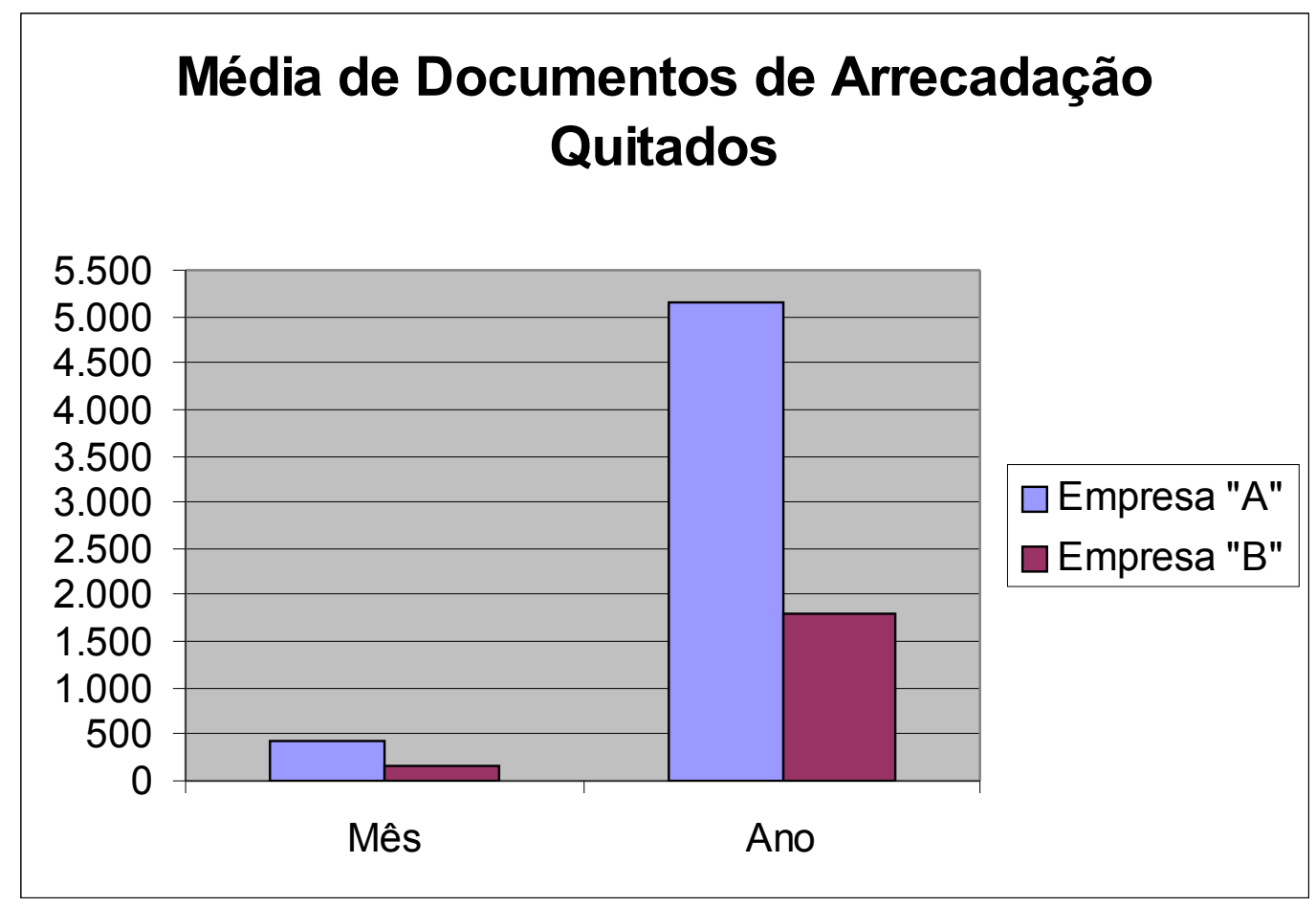

A figura 12 (doze) apresenta em forma de gráfico a média de documentos de arrecadação municipal emitidos por mês e por ano pelas empresas Serpro e Finep.

\section{5 - Descumprimento das obrigações acessórias}

No caso da Finep, não há risco quanto ao descumprimento de obrigações acessórias em razão de que a mesma somente tem envolvimento com a Prefeitura do Município do Rio de Janeiro. Quanto ao Serpro, os riscos são consideráveis na medida em que a empresa possui diversas regionais e escritórios, sendo que na maioria destas as prefeituras consideram a empresa como substituta tributária em seu relacionamento. Assim como descrito no quadro 5 acima, além de verificar itens como fato gerador, e vencimentos dos impostos retidos, ainda é dever da empresa o cumprimento de obrigações acessórias cujas informações são enviadas por meio eletrônico através de acesso às páginas das referidas prefeituras.

\section{6 - Rotinas internas desenvolvidas - Obrigações Acessórias}

No Serpro, foi armado um processo que leva em consideração o fluxo dos documentos fiscais. Ao dar entrada no setor responsável pela analise tributária, o documento fiscais é 
validado em todos os seus campos, sendo que no caso de haver alguma incorreção é devolvido imediatamente para as devidas correções. Tal procedimento visa da agilidade aos procedimento de registros dos diversos seguimentos da contabilidade, evitando que ao se chegar para o registro contábil seja identificado alguma incorreção no documento fiscal e assim se perder todo o tempo passado nos processos anteriores, que deverá se repetir quando da nova entrada do documento.

Na Finep, o Departamento de Contabilidade destaca um grupo de analistas para o atendimento as obrigações legais.

\section{7 - Renovação do quadro de empregados}

Assim como na Finep a renovação do quadro de empregados do Serpro se dá através de concurso público. Ocorre que no Serpro, a quantidade de empregados admitidos para exercerem funções financeiras não atendem as expectativas do órgão, acarretando acumulo de trabalho para outros empregados. Conforme já dito anteriormente, a saída para o problema está no desenvolvimento de aplicativos que auxiliem nas rotinas operacionais, tanto do departamento que cuida da análise da documentação financeira, quanto do departamento contábil.

\section{8 - Fiscalização Municipal}

Nos últimos cinco anos, não houve nenhuma fiscalização municipal na Finep, enquanto que no Serpro, a empresa foi fiscalizada por pelo menos cinqüenta municípios, sendo que em todas não houve notificações.

\section{9 - Retenção na Fonte por parte de clientes públicos}

A Finep em sua resposta ao questionário, respondeu que não presta serviços aos órgãos públicos.

No caso do Serpro a quase totalidade de serviços prestados são voltados para a esfera pública. Neste particular, em razão da capilaridade da empresa, que emiti Notas Fiscais de acordo com o local da prestação dos serviços, e, sendo o pagamento das faturas realizado de forma centralizado pela maioria de seus clientes, quando da realização dos documentos de quitação, muitos daqueles clientes, ou se esquecem de realizar a retenção, ou o fazem de forma 
incorreta, sendo que em alguns casos utilizando percentuais a menor.

\subsection{0 - Retenções indevidas}

Na Finep não há ocorrências de retenções indevidas.

No Serpro, em muitos dos casos, a empresa calcula e recolhe o imposto, tendo em vista que em alguns municípios nossos clientes não são considerados substitutos tributários. Ocorre que por desconhecimento da legislação, quando do efetivo pagamento da fatura, estes clientes retêm o imposto na fonte, e também realizam o recolhimento às prefeituras. Ai vem o impasse, por mais que o analista da área de faturamento explique ao cliente sobre a falha, estes não consideram as argumentações, e desta forma só resta a empresa entrar com pedido de restituição junto a Secretaria de Fazenda Municipal, que só efetua o ressarcimento após muitos meses, e em alguns casos leva-se até anos para a devolução do recurso. Foi feito um comentário que há um processo de solicitação de ressarcimento junto à Prefeitura Municipal de São Paulo que já dura mais de quatro anos. Prefeituras tais como Goiânia, Cuiabá, Belém, Porto Velho, Recife, Natal, Belo Horizonte, Curitiba, dentre outras, possuem registro na contabilidade da empresa, em conta de impostos a serem ressarcidos por duplicidade de recolhimento.

Todas estas dificuldades, foram trazidas pela imputação da substituição tributária. Nos parece que há um descaso por parte dos órgãos arrecadadores municipais, que ao serem oficializados a devolverem recursos repassados em duplicidade não dão a urgência que o assunto merece, nem tão pouco informando ao contribuinte sobre o andamento regular dos processos. Ainda há um medo, não justificado por parte do contribuinte, que para não receber em seus domicílios os fiscais, que com certeza irão encontrar alguma falha nos processos para minimizarem a devolução dos recursos pagos indevidamente, não insistem em procurar junto aos órgãos competentes os seus direitos. 


\section{5 - Conclusões}

Do ponto de vista da apuração dos impostos incidentes sobre as vendas, os profissionais responsáveis pela emissão e controle das Notas Fiscais, contam com um sistema bem consolidado e altamente confiável para o tratamento tanto de todos os clientes como da legislação que permeia todos os municípios onde a entidade entrega os serviços, e desta forma consegue identificar quais os clientes são considerados substitutos tributários perante os municípios onde estão instalados. No sistema os clientes são classificados de acordo com sua condição enquanto tomador de serviços. Esta é uma providencia de suma importância pois no caso do Serpro, mais de mil documentos fiscais são emitidos todos os meses, o que fica impossível de se realizar tratamentos manuais para definição dos cálculos de todos os tributos que envolvem as transações comerciais da empresa. Nota-se claramente as dificuldades que a empresa encontra neste particular, pois precisa conhecer além da legislação que lhe é imposta por sua própria existência, conhecer também a legislação imposta aos tomadores de serviços, que na grande maioria são da área pública. Mesmo com toda esta gama de conhecimentos, não é suficiente para a correta aplicação da legislação por parte dos clientes, que se confundem quando da realização dos pagamentos retendo na fonte o imposto municipal quando não necessitariam de fazê-lo. Nestes casos os retornos destes impostos retidos e recolhidos incorretamente, se tornam complicados, em razão dos processos burocráticos das prefeituras, que ainda não estão preparadas para analise e autorização de pagamento em tempo mais curto. Para a solução deste problema, os decretos que definem as entidades que deverão ser consideradas para efeito da responsabilidade tributária, poderiam excluir do rol das empresas obrigadas ao cumprimento destas obrigações aquelas empresas públicas que mantém contratos assinados com entidades públicas. Se a questão é tão somente relacionada à redução da sonegação fiscal, este tipo de fraude não ocorre entre nas empresas públicas em razão de sua própria condição jurídica. São tantos os órgãos de controle e tantas legislações que imputam ao administrador público responsabilidades por fraude, ou falhas que levam os profissionais do controle interno a se revestirem de condições seguras quanto o cumprimento do correto recolhimento dos impostos. Outro fator importante nestas considerações esta no fato de que os clientes públicos ao atrasarem os pagamentos de suas obrigações, fazem com que as prefeituras só recebam o tributo muitos meses após a prestação dos serviços, fato que não ocorria antes da publicação da Lei complementar $n^{\circ} 116$ (BRASIL, 2003).

Do outro lado do problema em estudo, as empresas tomadoras de serviços poderiam deixar de serem consideradas substitutas tributárias na medida em que as novas tecnologias, as 
novas formas de tratamento das obrigações acessórias, e de emissão de documentos físcais de forma eletrônica, modernizam as administrações municipais assim solucionando de vez o eterno problema da sonegação fiscal.

Por extensão, as prefeituras também poderiam implantar, ou utilizar o repositório da união, que está arquivando num primeiro momento, por meio do Sped, a contabilidade de todas as empresas optantes pela apuração dos resultados tendo por base o Lucro Real, devendo esta determinação se estenderem a todas as empresas num curto espaço de tempo. Desta forma, este tipo de procedimento será mais uma possibilidade de reduzir a carga tributárias das empresas, caso seja utilizada pelas prefeituras.

Em razão das tecnologias existentes que reduzem os custos tanto para o contribuinte como para a gestão da municipalidade, os administradores tributários devem reduzir a carga excessiva de obrigações impostas aos contribuintes, principalmente as relacionadas ao cumprimento das obrigações acessórias, e em função da instalação de mecanismos de controle por meio eletrônico, assim como fez a administração tributária dos estados e do governo federal, utilizar extratores ligando diretamente os computadores da administração municipal aos computadores das empresas como meio de reduzir a sonegação fiscal e desobrigando os prestadores de serviços de ter que prestar informações sobre seus movimentos comerciais, na medida em que se conhecerá previamente o que será arrecadado.

A exemplo do Município de São Paulo as outras administrações municipais deveriam agilizar os processos legais para implantação da Nota Fiscal eletrônica, pois os benefícios tanto para a sociedade quanto para as empresas são enormes, tais como: redução de custos de impressão e armazenamento de documentos fiscais; dispensa da emissão de autorização para Impressão de Documentos Fiscais - AIDF; utilização dos dados pelo tomador dos serviços; geração automática de guia para recolhimento através da internet; envio das Notas Fiscais ao tomador dos serviços através da internet; dispensas do registro das Notas Fiscais na Declaração Eletrônica de Serviços; redução da utilização de papel na medida em que os documentos são eletrônicos e arquivados em sistema de informática.

A reforma tributária agora em tramitação na Câmara dos Deputados, que propõe alterações no Sistema Tributário Brasileiro através da Proposta de Emenda à Constituição PEC $n^{\circ} 233 / 2008$, ao ser aprovada deverá desonerar as empresas tornando mais justo a carga tributária e a distribuição da riqueza.

Nos moldes que a PEC se apresenta, o Governo pretende simplificar e desburocratizar o Sistema Tributário, com uso dos recursos de informática, implementando como já dito acima, a Nota Fiscal eletrônica e integrando os físcos das três esferas de governo repassando 
informações, que visem dar mais eficiência ao sistema de fiscalização dos entes federados.

Finalizando, as decisões para a redução da carga tributárias das empresas são de implementação relativamente fácil, devendo para tanto sofrer a intervenção dos gestores públicos que possuem responsabilidade para tal. 


\section{REFERÊNCIAS}

ALMEIDA, A. M.; MACHADO, E. B.; CESERO, ANDRE De. Arrecadação moderna e simplificada. Tema - Revista do Serpro. Brasília, Ano XXXII, n. 195, p. 10-17, nov./dez. 2008.

BRASIL. Constituição da República Federativa do Brasil (1988). Lex: legislação federal e marginalia, Brasília, art. 37, 1988.

BRASIL. Lei $n^{\circ}$ 8.666, de 21 de junho de 1993. Lex: coletânea de legislação: edição federal, Brasília, v.1, 1993. Suplemento.

BRASIL. Ministério da Administração e Reforma do Estado (MARE). Instrução Normativa no 5. Brasília, DF, 1995. Suplemento.

BRASIL. Lei ${ }^{0}$ 5.172, de 25 de outubro de 1966. Lex: coletânea de legislação: edição federal, Brasília, v.1, 1966. Suplemento.

BRASIL. Lei n ${ }^{\circ}$ 8.137, de 27 de dezembro de 1990. Lex: coletânea de legislação: edição federal, Brasília, v.1, 1990. Suplemento.

BRASIL. Lei Complementar $n^{0}$ 116, de 31 de julho de 2003. Lex: coletânea de legislação: edição federal, Brasília, v.1, 2003. Suplemento.

BRASIL. Decreto $n^{0}$ 25.508, de 19 de janeiro de 2005. Lex: coletânea de legislação: edição federal, Brasília, v.1, 2005. DODF. Suplemento.

CARraZA, Roque Antônio. Curso de Direito Constitucional Tributário. São Paulo: Malheiros, 1999.

CEZAROTI, G. A. Tributação dos Serviços na Constituição Federal, o novo código civil e a lei complementar 116/2003. São Paulo: Quartier Latin, 2006.

COELHO, S. C. N. Curso de direito tributário brasileiro: (comentários à Constituição e ao Código tributário nacional, artigo por artigo). Rio de Janeiro: Fornece, 2001.

GASKELL, G. Entrevistas individuais e grupais. In BAUER, M W. GASKELL, G. Pesquisa qualitativa com texto, imagem e som: um manual prático. Petrópolis, RJ: Vozes, 2002. p.64-88. 
HARADA, K. Direito Financeiro e Tributário. 16. ed. São Paulo: Atlas, 2007.

JUNIOR, J. J. M. Substituição tributária no ISS: retenção. Considerações Gerais para sua compreensão. Jus Navigandi, Teresina, ano 8, n. 406, 17 ago. 2004. Disponível em: http://jus2.uol.com.br/doutrina/texto.asp?id=5591. Acesso em: 17 fev. 2009.

MACHADO, R. B. ISS na Lei Complementar n 116/2003. São Paulo: Quartier Latin, 2004.

MARTINS, Ives Gandra da Silva. ISS: Uma proposta para terminar a guerra fiscal. Universo Jurídico, 28 fev. 2007. Disponível em: http://uj.com.br/publicacoes/doutrinas/defaut.asp? action $=$ doutrina $\&$ coddou $=3485$.

MELO, J. E. S. de. Aspectos Teóricos e Práticos do ISS. São Paulo: Dialética, 2000.

NOGUEIRA, R. W. L. ISS (Imposto sobre Serviços): responsabilidade tributária. Jus Navigandi, Teresina, ano 10, n. 1181, 25 set. 2006. Disponível em: http://jus2.uol.com.br/doutrina/texto.asp?id=8970 >. Acesso em: 17 fev. 2009.

NUNES, A. G. Responsabilidade tributária de ISS sobre ente público. Jus Navigandi, Teresina, ano 10, n. 1101, 7 jul. 2006. Disponível em: http://jus2.uol.com.br/doutrina/texto.asp?id=8612. Acesso em: 17 fev. 2009.

OLIVEIRA, A. J. A de. A substituição tributária do Imposto sobre Serviços de Qualquer Natureza e a guerra fiscal entre os Municípios. Jus Navigandi, Teresina, ano 8, n. 288, 21 ago. 2004. Disponível em: $<$ http://jus2.uol.com.br/doutrina/texto.asp?id=5109>. Acesso em: 17 fev. 2009.

OLIVEIRA, L. M. de. et al. Manual de Contabilidade Tributária. 5. ed. São Paulo: Atlas, 2006.

PÊGAS, P. H. Manual de Contabilidade Tributária. 5. ed. Rio de Janeiro: Freitas Bastos, 2007.

RICHARDSON, Roberto Jarry. Pesquisa Social: métodos e técnicas. São Paulo: Atlas, 1999. p. 82-209.

RODRIGUES, W. P. Substituição Tributária. São Paulo: Quartier Latin, 2004. 
PIMENTA, A. Seis passos para sair do caos. Revista Exame, São Paulo, 939 ed. ano 43, n. 5, p. 40-45, 2009.

SABBAG, E. M. Direito Tributário. 6. ed. São Paulo: Prima Cursos Preparatórios, 2004.

VERGARA, S. C. Começando a definir a metodologia. In: pesquisa em administração. 3. ed., São Paulo: Atlas, 2000. cap. 4, p. 46-53. 